\title{
THE INTERNAL STRUCTURE OF EPA RULEMAKING
}

\author{
Thomas O. McGaritY*
}

\section{INTRODUCTION}

Twenty years ago, President Nixon assembled a loose amalgam of bureaucrats with widely varying institutional backgrounds from several existing regulatory programs and called it the Environmental Protection Agency.' Fundamental to the concept of a single integrated agency was the conviction that an interdisciplinary perspective was essential to rational environmental policymaking. However, in the rush to assemble an agency to implement the ambitious regulatory programs that Congress was enacting at breakneck speed, ${ }^{2}$ EPA's early leaders had little time for thinking about how to structure the decisionmaking process most effectively to harness the competing perspectives necessary for sound environmental decisions. The first few important rules (for example, the original National Ambient Air Quality Standards and the first round of the technology-based standards under the Clean Water Act) were largely products of single offices within the

Copyright $\odot 1991$ by Law and Contemporary Problems

* William Stamps Farish Professor of Law, University of Texas School of Law.

The author would like to express his appreciation to Ms. Melanie Neal for her help in arranging and conducting many of the interviews upon which this article is based.

1. See Richard A. Harris \& Sidney M. Milkis, The Politics of Regulatory Change: A Tale of Two Agencies 229 (Oxford U Press, 1989). Harris and Milkis conclude too easily that the initial employees of EPA were environmental zealots. Id at 231. While some of the new hires at EPA joined the agency out of a strong ideological desire to protect the environment, most of the original employees that came from existing departments were anything but environmental zealots. See also Alfred A. Marcus, Promise and Performance: Choosing and Implementing an Environmental Policy 35-43 (Greenwood Press, 1980). Landy, Roberts, and Thomas note:

The agency ... was initially staffed primarily by bureaucrats transferred from other federal departments. Mostly scientists and engineers, they had long labored in the bowels of large departments. ... [T]hey brought with them the concepts, attitudes, and skills that had served their former agencies. ... By both training and conviction, they were not prepared to shift from being aid and advice givers to aggressive violation hunters.

Marc K. Landy, Marc J. Roberts \& Stephen R. Thomas, The Environmental Protection Agency: Asking the Wrong Questions 34 (Oxford U Press, 1990) ("Asking the Wrong Questions"). Indeed, many managers in the old line agencies were delighted with the creation of EPA and gladly took advantage of the personnel transfers to unload some dead wood.

2. The agency currently has important regulatory responsibilities with respect to the following statutes: National Environmental Policy Act of 1969, 42 USC $\$ \$ 4321$ et seq (1990); Clean Air Act, 42 USC $\S 87401$ et seq (199l); Federal Water Pollution Control Act, 33 USC $\$ \S 1251$ et seq (1982); Resource Conservation and Recovery Act of 1976, 42 USC $\$ \S 6901$ et seq (1982); Toxic Substances Control Act, 15 USC $\$ \$ 2601$ et seq (1982); Federal Insecticide, Fungicide, and Rodenticide Act. 7 USC $\S \S 136$ et seq (1982); Safe Drinking Water Act, 42 USC $\$ \S 300 \mathrm{~F}$ et seq (1982); and Comprehensive Environmental Response, Compensation, and Liability Act of 1980, 42 USC $\S 9601$ et seq (1982). 
growing EPA bureaucracy, and they reflected very little input from professionals in the other programs. In the beginning, each office was so busy struggling to stay abreast of its own agenda that few mid-level professionals kept track of the activities of their counterparts in the other programmatic offices.

Unlike the older bureaucratic legacies of the Progressive and New Deal eras, Congress directed the modern health and environmental agencies to be proactive promulgators and enforcers of rules, rather than neutral adjudicators. Delegating extraordinary powers to EPA, Congress demanded that the agency regulate important aspects of industrial life in fundamental ways. This feat was to be accomplished through informal rulemaking, a process that merely provided the public with notice of the terms or substance of the agency's proposal, allowed members of the public an opportunity to comment on the proposal, and provided the agency's reasons for adopting its final rule along with its responses to important critical public comments.

The agency's vast discretionary powers did not go unconstrained for very long. As the federal courts of appeal began to hear challenges to EPA's early regulations, a body of administrative law began to develop around the "arbitrary and capricious" test for substantive judicial review, and the "hard look" doctrine replaced a more deferential view of the role of the reviewing court. In addition, President Nixon created the "quality of life" review process for subjecting EPA rules to internal checks within the administration, and that process gradually evolved into the highly structured (though always controversial) Office of Management and Budget ("OMB") review process currently in effect under Executive Order 12291.3 Finally, Congress has maintained an acute interest in the regulations that EPA writes, and its oversight of EPA decisionmaking has always been intense and highly demanding of the political appointees at the top of the agency. Although the influence of each of these external institutional actors on EPA rulemaking has varied over time, their combined impact has been enormous. ${ }^{4}$

The exigencies of external review and the practical necessities of bringing multiple perspectives within EPA to bear on the decisionmaking process determined, to a large degree, the structure of that process. As the agency evolved, upper-level agency managers made choices about how decisions would be made within the agency, and those choices greatly affected the allocation of power within the institution. Most bureaucratic entities pursue institutional power with the same vigor that they shun accountability. As in all bureaucratic institutions (in both government and the private sector), great turf battles have been waged in EPA over institutional power. Much can be learned about the relative status of agency subunits by observing the structure

3. Executive Order No 12291, 3 CFR 127 (1982).

4. See Richard J. Lazarus, The Tragedy of Distrust in the Implementation of Federal Environmental Law, 54 I. \& Contemp Probs 311 (Autumn 1991); Robert Glicksman \& Christopher H. Schroeder, EPA and the Couts: Twenty lears of Law and Politics, 54 L \& Contemp Probs 249 (Autumn 199I); Richard J. Pierce, Jr., Two Problems in Administrative Law: Political Polarity on the District of Columbia Circuit and Judicial Deterrence of Agency Rulemaking, 1988 Duke L.J 300, 326. 
of agency decisionmaking. Who may launch a rulemaking initiative? Who may participate in drafting the rule and its associated technical support documents? Who can delay the progress of a rule? Who has the responsibility for ensuring that the rule is promulgated in a timely fashion? Who is in a position to veto a rulemaking initiative, and at what cost? All of these questions critically affect and are affected by the allocation of institutional power. And the allocation of power within an agency can, in critical ways, determine its substantive output. ${ }^{5}$

This article will examine EPA's evolving internal decisionmaking structures as they relate to the agency's primary function of promulgating rules and regulations. Initially, it observes that the New Deal concept of the "expert agency" breaks down in the modern context of health and environmental regulation. An agency addressing complex scientific, economic, and technological issues must draw upon so many different kinds of expertise that no individual employee can know very much about all of the issues involved in a typical rulemaking. Drawing on interviews with EPA employees conducted during the past six years, ${ }^{6}$ the article will examine EPA's unique version of "bureaucratic pluralism"7 as manifested in the "team" model that has come to dominate EPA's institutional thought process. The article will next explore how, under the team model and alternative

5. Landy, Roberts, and Thomas correctly suggest that more than structure is necessary to integrate perspectives from diverse disciplines:

Integration is partly a matter of structure: the crafting of occasions and relationships so that relevant specialties come together to raise questions and to respond to each other's concerns. Structure alone, however, is insufficient. Integration also involves behavior and hence a concern for recruitment and reward patterns that foster the preferred behavior. An agency needs to attract people who have the capacity and desire to work with and learn from those with other points of view. Patterns of promotion must reflect these integrative commitments.

Landy, Roberts \& Thomas, Asking the Wrong Questions at 15 (cited in note 1). Reward structures and recruitment patterns, however, are beyond the scope of this article.

6. The author has interviewed more than 50 current and former EPA officials over a six-year period in connection with this and other studies of EPA's rulemaking process. The first set of interviews was conducted during 1983 and 1984 in connection with a study that the author undertook for the Administrative Conference of the United States ("ACUS") on regulatory impact analysis in the federal government. See Agency Procedures for Performing Regulatory Analysis of Rules, I CFR § 305.85-2 (1991) (Recommendation No 85-2); Thomas O. McGarity, Regulatory Analysis and Regulatory Reform, 65 Tex L Rev 1243, 1246 (1987); Thomas O. McGarity, Reinventing Rationality: Regulatory Analysis in the Federal Government (Cambridge U Press, 1991). A second set of interviews was conducted in $\mathbf{1 9 8 6}$ to update the prior research and to provide background for a study for ACUS on decisionmaking in the Occupational Safety and Health Administration. See Priority Setting and Management of Rulemaking by the Occupational Safety and Health Administration, 1 CFR § 305.87-1 (1991) (Recommendation No 87-1). See also Sidney A. Shapiro \& Thomas O. McGarity, Reorienting OSHA: Regulatory Alternatives and Legislative Reform, 6 Yale J Reg 1 (1989).

Finally, a third set of interviews was undertaken in the fall of 1990 to update previous research for this article. Although many of the earlier interviews were conducted on the record, most of the recent interviewees declined to speak for atribution. To avoid undue emphasis on earlier interviews, this article will cite a particular interview only where necessary to provide a source for a direct quotation. The reader should understand, however, that much of the description of the real-world decisionmaking process in Part III of this article and many of the insights presented throughout the article came from the dedicated EPA employees who were kind enough to contribute their time to conversations with the author and his research assistant.

7. Landy, Roberts \& Thomas, Asking the Irong Questions at 12-13 (cited in note 1). 
models, one or another institutional actor gains or loses institutional power and how the influence of one or another office affects the substantive outcome of internal agency debates. Finally, the article will describe and analyze four alternative models for bureaucratic decisionmaking, some of which have been used at EPA, and it will make some tentative suggestions about how the agency might choose among the available models in different decisionmaking contexts.

\section{II}

\section{“Expertise” in the Modern Regulatory Arena}

In the paradigm of the regulatory agencies created during the New Deal, the regulatory process focused upon a single industry or a discrete group of related economic problems with the goal of correcting market imperfections. A regulatory agency could over time acquire sufficient expertise in a particular subject matter to second-guess private sector decisionmakers on limited questions, such as the appropriate rates for natural monopolies to charge, the "correct" supply of an agricultural product, or the amount of information that should be communicated to consumers of fur coats. While some agencies had to assemble more than a single type of expertise, the experts were quite compartmentalized. Rarely did a decision require the application of more than one or two kinds of expertise, and even more rarely did an issue precipitate a clash among two or more sources of agency expertise. ${ }^{8}$

The modern federal agencies that administer "social" regulatory programs do not comfortably fit within the New Deal paradigm. EPA's regulations must protect many classes of beneficiaries from a multitude of harms resulting from an enormous variety of sources ranging from industrial effluent to household garbage. The extraordinarily ambitious statutes that Congress has written for EPA require the application of a wide variety of expertise. For example, to regulate photochemical oxidants under the Clean Air Act, EPA must draw upon expertise in toxicology, epidemiology, and the etiology of lung diseases to establish the national primary ambient air quality standards; expertise in atmospheric chemistry to understand the complex relationships between precursor pollutants (reactive hydrocarbons and oxides of nitrogen) and the photochemical oxidants that cause smog; expertise in air pollution dispersion modeling to understand the extent to which individual sources contribute to the overall problem; expertise in stationary source technology to understand what individual sources can do to limit direct and

8. One exception to this generalization might be the earlier manifestations of the Federal Trade Commission. In its modern day manifestations, the agency economists in the Bureau of Economics and the agency lawyers in the Bureau of Competition have frequently clashed over the proper approach to take to a rulemaking proposal. See Robert A. Katzmann, Regulatory Bureaucracy: The Federal Trade Commission and Antitrust Policy 180-85 (MIT Press, 1980); James Clifford Miller, The Economist as Reformer: Revamping the FTC, 1981-1985 (Am Enterprise Inst for Pub Policy Research, 1989). Although the agency did not use rulemaking as a decisionmaking tool before the $1960 \mathrm{~s}$, it is entirely possible that the agency's lawyers and economists disagreed on issues that arose in FTC adjudications. 
fugitive emissions into the atmosphere; expertise in mobile source technology to understand what manufacturers can do to limit emissions from automobiles, trucks, trains and airplanes; expertise in transportation and urban planning to understand how modifying driving patterns and urban mass transportation can reduce mobile source emissions; expertise in economics to understand how much all of this will cost and who will pay the bills; expertise in environmental law to understand the agency's authority to adopt various options and to predict how the courts will react to the rule and the relevant support documents; expertise in enforcement to understand the extent to which compliance with relevant regulations can be induced in the real world; and expertise in politics to predict how important constituencies will react and how their reactions will translate into pressure from powerful external actors in the White House, Congress, and elsewhere.

No individual within EPA has genuine expertise in all of the required areas. The administrator is typically a generalist with little expertise in any relevant topic. The agency staff can usually provide high-level political appointees with a rudimentary understanding of the relevant macro-issues, but agency decisionmakers must still rely heavily upon the staff's understanding of subtle nuances. Out of simple necessity, they must trust the staff to make the "right" calls on the scores of micro-issues that might form the basis for subsequent judicial challenges.

The expertise upon which the rulemaking edifice rests is thus an "institutional expertise" that transcends the knowledge and experience of any individual person or office within the agency. The success of a rulemaking initiative depends to a substantial degree upon the capacity of the institution to integrate the contributions of widely varying professional perspectives into a single coherent product. This is the essence of the "bureaucratic pluralism" that has necessarily come to dominate the rulemaking process in modern social regulatory agencies. Yet the matter is not as simple as merely soliciting the unencumbered scientific input from an assembly line of disinterested experts.

Each participant brings to the process more than just pure expertise on the limited issues to which that person's expertise is relevant. Along with the expertise comes an entire professional weltanschauung that incorporates attitudes and biases ranging far beyond specialized knowledge of particular facts. Thus, a decision that draws upon different kinds of expertise will necessarily reflect a mix of different professional perspectives. In the context of EPA, the mix of perspectives includes: (1) the scientific perspective (both pure and applied), (2) the engineering perspective, (3) the management perspective, (4) the enforcement perspective, (5) the "economic-analytical" perspective, (6) the legal perspective, and (7) the political perspective.

Health scientists are trained to relate environmental exposures to disease endpoints in sensitive populations. Materials scientists are interested in how pollutants interact with metals and other materials to cause damage. Ecologists are trained to identify complex and subtle changes in interacting 
ecological systems that result from externally induced stimuli like pollutants. The primary professional concern of all three groups is protecting health and the environment. These groups are less concerned with how exposures can be reduced (and how much that will cost) than with what will happen if they are not reduced or if they increase.

Environmental engineers, on the other hand, are trained to design and implement pollution control technologies. ${ }^{9}$ They focus almost exclusively on how pollutants can be eliminated from waste streams and then managed. For them a pound of pollutant removed is a benefit, irrespective of the damage that it would have caused had it remained in the waste stream. Although the engineers are cost-conscious, they are not especially concerned that the cost of a pollution reduction technology is exceeded by its monetized benefits. Instead, they prefer to search for the "knee of the cost curve"-the point at which the cost per pound of pollutant removed begins to rise at a very rapid rate-in deciding whether costs are excessive.

Managers are trained to get a particular job done within specific time and quality constraints. The job of EPA's managers is to shepherd the rulemaking process along in an efficient way to produce rules that will survive judicial and political review. Managers have expertise in making things happen. They attempt to foresee and avoid or overcome roadblocks to agency action, which may be political, practical, or monetary in nature. Managers are pragmatic people who "know the ropes," and they tend to be a bit cynical about idealistic notions like preserving the environment and maximizing allocative efficiency. In sum, they are the agency's experts in "muddling through."

Enforcement professionals are often attorneys, but they can also have training in scientific and technical areas. They are primarily concerned with the degree to which those regulated adhere to agency commands. It is, therefore, important to them that the agency articulate its rules in unambiguous ways that both fairly apprise regulatees of conduct that is permissible and impermissible, and minimize the extent to which regulatees can avoid compliance through interpretational loopholes. Because their expertise is applied primarily at the interface between the government and the citizen, the enforcers tend to view the world as a "we-they" system in which the agency's job is to ensure that regulatees do not avoid the rules. Thus, while enforcement professionals might balk at alternative inducements such as effluent charges because they make it difficult to detect cheaters, enforcers are also opposed to such techniques in a more fundamental sense because

9. See Ted Greenwood, Knowledge and Discretion in Government Regulation ch 3 (1984). Landy, Roberts, and Thomas observe:

Engineers . . are trained to solve problems, not resolve them. The formulae and rules on which they base their calculations are often arbitrary. Nonetheless, they have been trained to use them to provide numerical solutions. They come to believe that there are right answers to problems. and that those can be arrived at by manipulating data according to a unique "best practice."

Landy, Roberts \& Thomas, Asking the Wrong Questions at 11 (cited in note 1). 
they do not clearly distinguish between socially acceptable and undesirable conduct.

The agency's economists and policy analysts come to the decisionmaking process steeped in the "comprehensive analytical rationality" 10 paradigm that dominates American economics departments and business and public policy schools. Under that model, the analyst must identify the regulatory problem and break it down into its constituent parts, define and rank the agency's goals, identify several options for solving the problem, assemble all of the relevant information, determine (usually by employing ambitious mathematical models) the extent to which each option advances one or more of the agency goals, and advocate the option that optimizes the agency's goals. For economists, all variables are continuous and present the decisionmaker with an infinite variety of trade-offs. "The economist/analysts are typically trained in the concepts and models of neoclassical microeconomics, and their regulatory philosophies reflect this training. ${ }^{12}$ Although they are prepared to concede that economic efficiency is not the only goal of the regulatory process, they tend to focus very heavily upon that goal in their analyses, sometimes to the exclusion of other agency goals. ${ }^{13}$ For them, the acid test for a proposed rule is whether its social benefits exceed its social costs. ${ }^{14}$

Legal training leads the agency's lawyers to take a highly analytical approach to solving regulatory problems that differs from the regulatory analysts' approach primarily in its failure to draw upon the economics discipline. Attorneys like to explore many options to a given regulatory result, but they are inclined to truncate the consideration of options that the agency has no power to implement. The lawyers are primarily concerned with

10. See Colin S. Diver, Policymaking Paradigms in Administrative Law, 95 Harv L Rev 393, 396 (1981); McGarity, 65 Tex L Rev at 1253 (cited in note 6).

11. Landy, Roberts and Thomas observe:

Unlike either lawyers or engineers, economists are trained to view all variables as continuous. Regardless of whether price, production, or consumption is at issue, choices are not "yes" or "no," but matters of amount or degree. Thus, economists instinctively see all issues as arenas for trade-off and outcomes that produce "a little of this and a little of that" are often judged desirable.

Landy, Roberts \& Thomas, Asking the Wrong Questions at 11 (cited in note 1).

12. See McGarity, Reinventing Rationality ch 2 (cited in note 6).

13. See Landy, Roberts \& Thomas, Asking the Wrong Questions at 11 (cited in note 1) ("To [economists] it is obvious that the correct test of a policy is its efficiency and that efficiency is defined by giving people as much of what they want as possible.").

14. Marcus suggests that the economists in the policy office reflect the "White House" view on environmental issues, as distinguished from the congressional point of view adopted by the program offices. Marcus, Promise and Performance pt I (cited in note 1). While it is true that in EPA's early years certain segments in the White House stressed that the agency should pay greater attention to costs and certain congressmen and senators urged the agency to forge ahead irrespective of costs, it is far too simplistic to view the fundamental division between the policy office and the program offices that has existed at EPA throughout its entire history as merely the struggle in microcosm between the president and Congress for EPA's soul. The clash of regulatory cultures that has characterized the relationship between these two offices is more a clash of disciplinary perspective. It has endured periods (like the Carter Administration) in which the White House was rather sympathetic to environmental goals and times (like the energy crises of the 1970s) in which Congress has not been sympathetic toward uncompromising pursuit of environmental ends. 
ensuring that the agency's regulations are within the agency's statutory power and that the technical and economic bases for its rules pass the minimum standards for substantive judicial review. Although attorneys tend to urge caution to private clients when they come near the edge of the law, agency lawyers typically stress the flexibility that the agency has under its statutes and urge the agency to probe the limits of its authority. This tendency was reinforced by the Supreme Court's Chevron holding that the reviewing courts are to take a very deferential approach toward agency statutory interpretation when the meaning of the words of the statute is unclear. ${ }^{15}$ Finally, the training that attorneys receive in law school leads them to emphasize procedural fairness. In the rulemaking context, this means a concern that all affected individuals and groups are able to participate fully in the process. ${ }^{16}$

Political expertise is not learned in school, but rather comes with experience. Nevertheless, it is critical to the success of the rulemaking enterprise. Agencies rarely staff a designated office with experts in politics, preferring instead to rely upon the political assessments of the politically appointed decisionmakers. Still, agencies usually have one or more de facto political experts, either in the "external affairs" office that deals directly with the legislature or on the staff of the head of the agency. Like the managers, the political experts tend to be pragmatists rather than idealists. They attempt to identify politically powerful constituencies that will be affected (beneficially and adversely) by a rule and provide advice on the best way to approach the political review that all important rules must endure.

Since each representative of each professional perspective described above comes to the decisionmaking process with particular conceptions and preconceptions about how the world does and should work, bringing together persons with expertise in all of the relevant disciplines presents a high potential for a clash. ${ }^{17}$ The clash can be immensely creative or devastatingly destructive. It must, therefore, be effectively managed if bureaucratic pluralism is to work. The management at stake here is not of the familiar sort (ensuring that rules are promulgated in an efficient way according to schedule); rather, the agency's management must be capable of policy management-ensuring that lower-level decisionmaking entities adhere to the policies articulated by upper-level policymakers. ${ }^{18}$ The success of this

15. See Chevron U.S.A., Inc. v Natural Resources Defense Council, Inc., 467 US 837, 844 (1984); Alfred C. Aman, Jr., Administrative Law in a Global Era: Progress, Deregulatory Change and the Rise of the Administrative Presidency, 73 Cornell L Rev 1101, 1107 (1988); Cass R. Sunstein, Interpreting Statutes in the Regulatory State, 103 Harv L Rev 405, 444-46 (1989).

16. See Landy, Roberts \& Thomas, Asking the Wrong Questions at 11 (cited in note 1).

17. For a description of some of the early clashes, see Marcus, Promise and Performance at 101-19 (cited in note 1 ).

18. Landy, Roberts, and Thomas, in their recent study of EPA during the Carter Administration, suggest that bureaucratic pluralism may not be a desirable approach to regulatory decisionmaking in EPA, because it hinders the agency in performing a public leadership and educational role. See Landy, Roberts \& Thomas, Asking the Wrong Questions at 12-13 (cited in note 1). They are no doubt correct in suggesting that structuring the decisionmaking process in a way that effectively delegates all of the important decisions to the "experts" at lower levels in the agency substantially diminishes the leadership role that politically appointed upper-level decisionmakers can play. But this ignores 
latter form of management depends heavily upon the structure of the decisionmaking process.

\section{III}

\section{InTRoduction to the Major Institutional ACtors}

An examination of EPA's current decisionmaking processes must begin with a description of the agency hierarchy and an introduction to the major institutional players. ${ }^{19}$ The administrator stands at the top of the hierarchy and is the most important institutional actor. $\mathrm{He}$ or she is the final decisionmaker on agency rules, the ultimate judge in agency adjudications, and the court of last resort in intra-agency turf battles. With the final say over the allocation of resources within the agency, the administrator determines agency priorities and decides which offices play what roles in the decisionmaking process. Finally, the administrator is the principal spokesperson for the agency and the primary focal point in interactions between the agency, the White House, Congress, and the public.

The deputy administrator is the second in command but (like the vicepresident) has only such institutional power as the administrator cares to delegate. For example, while Deputy Administrator Hernandez was essentially a nonentity during the Gorsuch Administration, Deputy Administrator Alm was assigned almost exclusive authority over rulemaking management during the second Ruckelshaus Administration while Ruckelshaus attempted to mend fences with Congress and to reassure a shaken public.

The next level in the formal hierarchy consists of the nine politically appointed assistant administrators. At this level of the hierarchy, the historical dual structure of the agency becomes most apparent. ${ }^{20}$ The agency is divided into both programmatic and functional areas. Each important regulatory program within the agency reports to a particular assistant administrator with programmatic responsibilities, but there are also assistant administrators for broad functions, such as resource management, research

\footnotetext{
the unavoidable fact that regulatory agencies have other equally important roles to play. While the agency has an obligation to educate the general public about what the agency is doing when it imposes expensive requirements on the regulated industries, alternative decisionmaking models exist to reduce the risk of poor policy communication. It is probably more important that the relevant elites in the White House, Congress, and the courts, who have the power to send the agency back to the drawing board, are convinced that the regulations have a sound technical basis and reflect the appropriate statutory policies. The authors probably overestimate the extent to which "the man on the stree" cares about the analytical approaches that the agency takes toward environmental regulation. EPA has probably fulfilled its public educational responsibilities when it has made the information upon which it relied available for public inspection and criticism and has satisfied the news media that it has not been captured by the industry. Indeed, if the agency attempted to assume a substantially more aggressive educational role than this, it would risk being written off as a governmental propagandist for a particular point of view.

19. Unless otherwise noted, the following description of EPA's hierarchy is drawn from the United States Government Manual 1990-91 (Office of the Fed Reg, Spring 1991) and from the Federal Yellow Book (Spring 1991).
}

20. See Marcus, Promise and Performance at 102 (cited in note 1). 
and development, enforcement, and policy management. Originally, there were five assistant administrators, only two of whom had programmatic responsibilities, ${ }^{21}$ but as the agency's regulatory responsibilities blossomed, and as the agency became more difficult to manage, new assistant administratorships were created. ${ }^{22}$ The current list of assistant administrators consists of the assistant administrators with programmatic responsibilities (the Assistant Administrators for Air and Radiation, for Pesticides and Toxic Substances, for Solid Waste and Emergency Response, and for Water) ${ }^{23}$ and those with overall functional responsibilities that cut across programmatic areas (the Assistant Administrators for Administration and Resource Management, for Enforcement and Compliance Monitoring, for International Activities, for Policy, Planning, and Evaluation, and for Research and Development). ${ }^{24}$

The Assistant Administrator for Enforcement and Compliance Monitoring has the primary responsibility for enforcing EPA rules. Together with attorneys from the Justice Department, the lawyers for the Office of Enforcement and Compliance Monitoring investigate potential violations, prepare enforcement actions, negotiate with polluters, and prosecute civil and criminal actions in court. The office also has the responsibility for ensuring that the rules the agency drafts are easily enforced.

Although most of the program offices have economists on staff, the agency's principal regulatory analysts work in the Office of Policy and Compliance Monitoring Analysis under the Assistant Administrator for Policy, Planning, and Evaluation. This central regulatory analysis office, which functions as a "mini-OMB," has evolved through several agency reorganizations into a powerful institutional actor. ${ }^{25}$ It participates in every

21. The original EPA program offices consisted of the Office of Planning and Management, the Office of Enforcement and General Counsel, the Office of Media Programs, the Office of Categorical Programs, and the Office of Research and Monitoring. United States Government Organization Manual 1971-72, 632 (1972). This structure remained intact only until 1972.

22. At the outset, Douglas Costle, an aide to then-Administrator Ruckelshaus, suggested a plan whereby the assistant administrators with programmatic responsibilities would gradually be phased out and their operations lodged under the assistant administrator with functional responsibilities. This plan was abandoned and never resurfaced. See Landy, Roberts \& Thomas, Asking the Wrong Questions at 35 (cited in note 1); Marcus, Promise and Performance at 103-05 (cited in note 1).

23. Four of the assistant administrators-the Assistant Administrators for Air and Radiation, for Pesticides and Toxic Substances, for Solid Waste and Emergency Response, and for Water-bear responsibility for implementing the agency's regulatory programs. All of the substantive regulations that the agency promulgates must have the approval of one of these four assistant administrators, and all of the regulatory program offices fall under the jurisdiction of one or another of these assistant administrators.

24. The Assistant Administrator for Policy, Planning, and Evaluation is responsible for centralized regulatory analysis and overall program evaluation. The Assistant Administrator for Enforcement is responsible for enforcing agency regulations and coordinating enforcement actions with the states and the Department of Justice. The Assistant Administrator for Research and Development supervises agency-sponsored research and oversees several agency laboratories. The Assistant Administrator for Administration and Resource Management is primarily responsible for budgetary and management functions, and the Assistant Administrator for International Activities deals with increasingly important transnational issues.

25. The regulatory analysts in the Office of Policy, Planning, and Evaluation began their ascent during the Carter Administration when Administrator Costle sensed that the mood of the country 
important regulatory decision, often undertakes its own information gathering activities, relishes its role of institutional gadfly, and is the primary institutional proponent of market-oriented approaches to regulation.

The general counsel is the agency's chief attorney. The Office of General Counsel ("OGC") is divided programmatically and functionally, reflecting the dual organization of the agency. Under the general counsel and two deputy general counsels, there are seven associate general counsels with their associated staffs. ${ }^{26}$ OGC is responsible for legal interpretations underlying agency rules and for defending those rules in court. Its duty to ensure that rules survive "arbitrary and capricious" review justifies the office in taking positions on the substantive merits of proposals and on the technical and economic validity of the support documents. During the agency's early years, the OGC attorneys were usually bright young graduates of top law schools who were committed to social change. ${ }^{27}$ As time passed, some of the more idealistic attorneys departed (especially during the Gorsuch years). The office now appears less inclined to press hard for stringent environmental controls. ${ }^{28}$

The associate administrators are not as easy to place within the decisionmaking hierarchy. The associate administrator positions were created during the tenure of Administrator Gorsuch to shift the locus of institutional power from lower-level career employees to upper-level appointees. ${ }^{29}$ The fact that the new positions did not require presidential appointment or the advice and consent of the Senate allowed the administrator to staff the positions with loyal fellow travellers. The original Associate Administrators for Enforcement and General Counsel and for Policy and Resource

was shifting away from environmental activism and toward a greater regard for the costs of regulation. According to Harris and Milkis, Costle explained that the agency "wanted to be out in front in this situation in order to control its own destiny." Harris \& Milkis, The Politics of Regulatory Change at 250 (cited in note 1). The analysts continued to thrive during the Gorsuch years. While the budget for virtually every other office in the agency was cut during the early $1980 \mathrm{~s}$, the Office of Policy, Planning, and Evaluation received an increase in funding. Id at 257. The office, however, reached its zenith during the second Ruckelshaus administration, when Deputy Administrator Alm made it very clear to the other institutional actors that the analysts were first among equals.

26. The Associate General Counsel for Air and Radiation; the Associate General Counsel for Grants, Contracts, and General Law; the Associate General Counsel for the Inspector General; the Associate General Counsel for the International Division; the Associate General Counsel for Pesticides and Toxic Substances; the Associate General Counsel for Solid Waste and Emergency Response; and the Associate General Counsel for Water.

27. Harris and Milkis quote one early EPA official as saying: "Many of the lawyers that came on board in the early seventies were infused with a certain zeal for the environmental cause." Harris \& Milkis, The Politics of Regulatory Change at 244 (cited in note 1).

28. For example, in 1985 OGC reversed the Office's long-standing interpretation of the Clean Air Act to conclude that costs and attainment problems could be considered by the agency in setting National Secondary Ambient Air Quality Standards. Thomas Decides Cost Dala May Be Used to Set Secondary Standards, Official Says, 16 Envir Rep 865 (1985).

29. According to Harris and Milkis, the creation of a separate Associate Administrator for Enforcement and General Counsel served two functions: "Under the pretext of streamlining the agency, it gave Burford the opportunity to eliminate some 'unwanted lawyers.' More important perhaps, it helped to centralize control over enforcement actions, a generic approach of the Reagan Administration's deregulatory effort." Harris \& Milkis, The Politics of Regulatory Change at 255 (cited in note 1 ). 
Management were very powerful institutional entities. ${ }^{30}$ When Administrator Ruckelshaus returned to the agency, however, he drastically reduced the power of the associate administrators. He eliminated the Associate Administrator for Enforcement and General Counsel and for Policy and Resource Management and replaced them with Associate Administrators for Communications and Public Affairs, for Congressional and Legislative Affairs, and for Regional Operations and State/Local Relations. As their titles imply, the associate administrators are now concerned primarily with the agency's interactions with the world beyond Waterside Mall, ${ }^{31}$ and in that capacity they are repositories of political expertise.

The next level in the agency hierarchy (the highest level nonpolitical appointee) is the office director. Each of the assistant administrators is responsible for several offices, and each office director is typically responsible for one important program. The office directors are the actual managers of agency regulatory programs, and they are the officials primarily responsible for the substance of agency rules. They are also the officials most easily accessible to regulatees and important citizen groups. Typically an office director in one of the program offices assumes responsibility for all of the agency's substantive rules under a particular statute. ${ }^{32}$

The offices in turn are subdivided into divisions, each of which has programmatic or functional responsibilities. For example, the Office of Air Quality Planning and Standards contains the Air Quality Management Division (responsible for promulgating and overseeing the implementation of the National Ambient Air Quality Standards), the Emissions Standards Division (responsible for promulgating new source performance standards and national emission standards for hazardous air pollutants), the Stationary Source Compliance Division (responsible for compliance monitoring and technical support for enforcement), and the Technical Support Division (responsible for technical support for rulemaking and enforcement activities and for assembling national databases). Each office director is a senior civil service employee and is aided by a deputy director of almost equal status.

30. The Associate Administrator for Policy and Resource Management had a virtual veto power over any regulatory proposals of the assistant administrators. Personal interview with Mr. Joseph Cannon, Associate Administrator for Policy and Resource Management, Radiation, EPA, May 18, 1984.

31. EPA headquarters are located at the Waterside Mall at $410 \mathrm{M}$ Street SW, Washington, D.C. The edifice, which consists of two twelve-story buildings with an almost connecting three-story mall, became EPA's home in 1973 when an ambitious urban renewal project undertaken by one of Spiro Agnew's friends failed and was bailed out by the government. Since the connecting mall has never been completed, agency employees must still descend into the garage below the east wing of the building to travel from one wing to the other. The originally promised cafeteria may never be built.

32. Some statutes are broad enough to warrant more than one office. The Office of Air Quality Planning and Standards and the Office of Mobile Sources under the Assistant Adiministrator for Air and Radiation both implement programs under the Clean Air Act. The Office of Solid Waste and the Office of Underground Storage Tanks under the Assistant Administrator for Solid Waste and Emergency Response both implement programs under the Resource Conservation and Recovery Act, 42 USC $\$ \$ 6901$ et seq (1982). 
The staff sergeants of the agency are the branch chiefs, who are located just below the office directors in the agency hierarchy. Each branch chief supervises a staff of agency professionals who do the actual work of writing and compiling the technical support for agency rules. The branches are populated by scientists, engineers, and other professionals with training or experience in environmental management. Though by no means environmental zealots, the program office professionals tend to be more concerned about protecting environmental values than about the costs that are entailed in achieving those goals. ${ }^{33}$

Superimposed upon this entire structure are ten regional offices, each of which has a politically appointed regional administrator and a staff that reports to the regional administrator but is organized roughly along the lines of the headquarters staff. The primary functions of the regional offices are to oversee state and federal permitting processes, approve state implementation plans and delegations, conduct monitoring and enforcement efforts, and serve as representatives of the agency to the general citizenry.

The primary collective decisionmaking entity at EPA is the "Steering Committee," which is a standing group composed of high level representatives of each assistant administrator and the general counsel. ${ }^{34}$ The Steering Committee concept has been in use at the agency since its inception, and although its importance has waxed and waned through the years, it has proven remarkably durable. Its purpose is to coordinate and integrate the agency's regulation development activities. Its operational functions are to approve "start action requests," to charter and monitor the progress of staff-level workgroups (with an emphasis on cross-media and inter-office problems), and to ensure that significant issues that arise during the internal deliberations are resolved or elevated to upper-level management for resolution. ${ }^{35}$

Any office may submit documents for review or issues for resolution at the Steering Committee's biweekly (or more often if necessary) meetings. The Steering Committee is often an intermediate appellate forum for disputes that could not be resolved in the workgroups. At the end of each Steering Committee meeting, the chairman writes a "closure memorandum" that documents outstanding issues, agreements, and actions to be taken in the future. ${ }^{36}$ Each Steering Committee member is responsible for directing the flow of the documents from his or her office through the agency's regulation management system, for keeping track of relevant deadlines, and for coordinating his or her office's review of the products of other offices. In

33. Harris \& Milkis, The Politics of. Regulatory Change at 244 (cited in note 1).

34. For a discussion of the origin of the Steering Committee, see Marcus, Promise and Performance at $96-97$ (cited in note 1 ).

35. The Steering Committee, Fact Sheet 1, Regulation Management Series (EPA, May 1990 revision).

36. The Chairman of the Steering Committee is nearly always the Director of the Office of Regulatory Management and Evaluation in the Office of Policy, Planning, and Evaluation. 
addition, Steering Committee members are the representatives of their assistant administrators in the OMB review process.

\section{IV}

\section{The Decisionmaking Process}

EPA has one of the most highly developed internal procedures for generating rules of any agency in the federal government. ${ }^{37}$ Since most of EPA's major rules originate in one of five offices, the following analysis of the decisionmaking process in EPA will focus primarily upon those offices-the Office of Air Quality Planning and Standards, the Office of Toxic Substances, the Office of Solid Waste, the Office of Drinking Water, and the Office of Water Regulations and Standards.

\section{A. The Origin of EPA Rules}

Perhaps the most frequent source of EPA rules is a statutory command that the agency promulgate a particular rule by a specific deadline. ${ }^{38}$ EPA rules can also result from internal investigations and from petitions from environmental groups and industry. Rules originate in "lead offices" (sometimes referred to in this article as the "program offices") under the four assistant administrators with rulemaking responsibility. Although it may draw on other offices to complement its resources, the lead office is the primary source of technical expertise for the regulatory action. In addition to technical expertise, nearly all of the lead offices have expertise in economic analysis. Staff professionals in the lead offices supervise independent contractors who often do the bulk of the technical and economic data gathering for the agency rulemaking initiatives. The lead office is also responsible for organizing and chairing the workgroup for each rulemaking initiative, setting the schedule for the rulemaking process, and eliciting the participation of other agency offices and the public. The assistant administrator in charge of the lead office must designate a project officer to manage each regulation's development as it moves through the internal agency procedures.

During its early years, the agency did not have a formal mechanism for initiating rulemaking efforts. The relevant program office would make a tentative decision to proceed with a rulemaking initiative and write a memorandum to the administrator to that effect. This effort often precipitated a meeting with the administrator or a member of his immediate staff, and if no objections were raised, the initiative would proceed. As the agency grew and it became clearer that a rulemaking initiative in one office

37. One high-level staff employee at EPA, who had been in six different agencies over a nineyear period, commented that EPA has the most systematic process for issuing major rules that he had ever seen. Personal interview with Mr. John M. Campbell, Deputy Assistant Administrator for Policy, Planning, and Evaluation, EPA, June 29, 1984.

38. See, for example, Resource Conservation and Recovery Act of 1976,42 USC $\S 6921$ (b)(3)(C) (1982); Clean Air Act, as amended, 42 USC $\$ 7412(\mathrm{~b})(1)(\mathrm{B})(1982)$. 
necessarily required resource reallocations in other offices, this ad hoc process yielded to a more formalized approval process. The final result was a computerized "action tracking system" that tracks every important rule in the agency and measures current progress against predetermined "milestones." 39 The administrator (or any agency employee with a computer, for that matter) can now ascertain the status of any rulemaking initiative by merely accessing the action tracking system. The Office of Standards and Regulations under the Assistant Administrator for Policy, Planning, and Evaluation prints out a biweekly "due or late" list to remind all lead offices when they begin to slip behind schedule. The system is intended to highlight delays in the rulemaking process and to attach responsibility for those delays. ${ }^{40}$

Under the existing highly formalized internal procedures, the first step in a rulemaking initiative is the start action request that the lead office submits to the Steering Committee. ${ }^{41}$ The primary purposes of the start action request are to alert other agency officials to the lead office's intention to develop a rule and to provide the Steering Committee with an opportunity to discuss and plan for any inter-office and cross-media aspects of the rule. The request can also avoid duplication. If one office is aware that another office is working on a regulatory problem of interest to both offices, they can coordinate their efforts. Finally, the start action request provides the occasion for specifying and preparing for subsequent stages of the rulemaking process for the particular rule.

The start action request is a one-page printed form that is intended to (1) define the problem clearly, including its health and environmental significance; (2) indicate the effect of the problem and the intended regulatory action on other environmental media or programs; (3) identify the EPA regions and other groups that should be involved; and (4) specify the kind of expertise and level of participation expected from workgroup members. ${ }^{42}$

39. Memorandum on Action Tracking System, from Alvin L. Alm to Addressees 1, Sept 20, 1983 ("Alm Action Tracking Memo").

40. If an office has a good reason for moving a milestone forward in time, it may request the Office of Standards and Regulations to amend the schedule accordingly. This has the effect of postponing the time that the next step of the project appears on the due or late list. The requesting office must, however, explain the requested slippage, and that explanation itself is entered into the action tracking system. The original schedule and all amended schedules, logether with the slippage explanations, are retained in the system and may be called out of the computer at any time. The entire history of the project is thus available for inspection.

41. Except where otherwise noted, the following textual description of the internal decisionmaking process in EPA is drawn from the following sources: Fact Sheets 1-12, Regulation Management Series (EPA, May 1990 revision); Memorandum on Procedures for Regulation Development and Review from Alvin L. Alm, Deputy Administrator to Assistant Administrators, General Counsel, Inspector General, Associate Administrators, Regional Administrators, and Staff Office Directors, Feb 21, 1984 ("Procedures Memo"); Memorandum on Criteria and Guidelines for Review of Agency Actions from Alvin L. Alm, Deputy Administrator to Assistant Administrators, General Counsel, Inspector General, Associate Administrators, Regional Administrators, and Staff Office Directors, Jan 30, 1984 ("Criteria and Guidelines Memo").

42. Start Action Requests, Fact Sheet 1, Regulation Management Series (EPA, May 1990 revision). 
The start action request also provides the program office's assessment as to whether the rule will be "major,"43 "significant,"44 or "minor."45

The Steering Committee representative from the lead office must approve the start action request and determine whether it warrants discussion at the next meeting. During the mid-1980s, the Assistant Administrator for Policy, Planning, and Evaluation had the final authority to approve or disapprove a start action request, ${ }^{46}$ but that authority is now apparently lodged in the Steering Committee. ${ }^{47}$ Since the start action request is informational rather than functional, Steering Committee members rarely object to a program office initiating the action.

After the Steering Committee approves the start action request, it charters a workgroup, designates workgroup members from each of the affected agency offices, and determines what further reviews will be necessary. At this point, the ball is in the program office's court, and that office proceeds to work up the technical, economic, and legal support for the rule. By the time a start action request is approved, the program office has usually devoted some effort to defining the problem it intends to address and identifying some possible solutions. The program office's position on the direction the rule should take is often the product of informal give-and-take among the office's staff. Since most program offices have their own economists, that perspective is often represented at these early problem-definition stages. In some offices, internal teams are assembled to formulate the positions that the program office will take when it interacts with other offices in the agency and with upper-level management. These informal intra-office groups can identify useful options prior to airing a proposal in the workgroup or Steering Committee. In several offices, representatives from OGC and the Office of

43. "Major" rules are those for which Regulatory Impact Analyses must be prepared under Executive Order No 12291, 3 CFR $\S 127$ (1982). A "major rule" is any regulation that is likely to result in:

(1) An annual effect on the economy of $\$ 100$ million or more;

(2) A major increase in costs or prices for consumers, individual industries, Federal, State,

or local government agencies, or geographic regions; or

(3) Significant adverse effects on competition, employment, investment, productivity, innovation, or on the ability of United States-based enterprises to compete with foreignbased enterprises in domestic or expert markets.

Id $\S 1(b)$.

44. A rule is "significant" if it is not "major" but nonetheless will have important effects on the environment, public health, or the economy, will present inter-media issues, or will affect the administration or operation of several EPA offices. Procedures Memo at 2 (cited in note 41 ).

45. "Minor" rules are those that are neither "major" nor "significant." They include the more specialized and routine rules that affect only one program or sector of the economy, or that simply implement established agency policy. Id.

46. Criteria and Guidelines Memo (cited in note 41); Telephone interview with Daniel Fiorino, Acting Director, Regulation and Enforcement Management Division, Office of Standards and Regulations, Office of Policy, Planning and Evaluation, EPA, May 23, 1984

47. Although disapproval of a start action request may have been a realistic possibility at one time, it so seldom happened that start action requests were routinely ignored by some program offices and treated on a pro forma basis by many others. In recent years, most offices have prepared start action requests, but they are all pro forma in the sense that initiatives are never halted at that early stage. 
Policy, Planning, and Evaluation ("OPPE") are invited to attend the intraoffice meetings, but resource limitations usually prevent the assignment of a lead analyst or lead attorney to an internal meeting prior to the time that a workgroup is formed.

\section{B. The Workgroup}

1. The Role of the Workgroup. Shortly after the Steering Committee approves a start action request, the project officer in the lead office must convene a workgroup. The workgroup is chaired by the project officer from the lead office, and it contains the lead analyst from the Office of Policy Analysis, a staff attorney from OGC, and usually staff representatives of the Office of Research and Development, the Office of Enforcement and Compliance Monitoring, and a regional office. Other offices may send representatives when the workgroup will be addressing issues that concern them. In practice, the project officer can attempt to arrange for particular individuals from the other offices to be assigned to his or her workgroup. EPA's regulation management training materials somewhat facetiously warn prospective project officers that finding the best people to become members of the workgroup is not as important as avoiding the worst staffers; they particularly caution against placing "rookies" 48 and "bastards" 49 on the team.

Attendance at workgroup meetings for unexciting rules can be erratic. The analysts in the Office of Policy Analysis and the attorneys in OGC are usually too busy to attend all of the workgroup meetings for rules that they consider unimportant. The Office of Enforcement is so pressed for time that the presence of a representative from that office at workgroup meetings is often the exception rather than the rule. Sporadic workgroup attendance can, however, lead to friction when nonparticipating offices raise objections or identify fresh options at the "sign-off" stage very late in the standard development process. The lead offices justifiably complain that it is unfair for the other offices to take "late hits" when they could have raised their objections at the workgroup level.

48. A "rookie" is described as

the poor schmuck who is just in the door and is assigned to the Workgroup because he is low man. The rookie should be avoided, not because of personal incompetence, but rather because of lack of institutional experience. You cannot count on them to represent their office. Usually, they do not have full knowledge of their office's program or concerns. In addition their access to their management is often limited. That means extra work for the chairman to identify that office's positions or risk being blindsided later in the process.

William R. Diamond, Practical Aspects of Workgroup Operations, in Regulation Development in EPA 5 (EPA, 1989) (materials prepared for training new EPA employees).

49. A "bastard" is described as

the person found in many offices who has his own agenda and cannot be controlled by his office. The problem here is that these loose cannons guarantee delay and disruption. They exhibit a fanatic unwillingness to compromise and a penchant for loving to hear themselves talk. Other traits are a lack of a sense of perspective of the relative importance of the issucs and a propensity to beat dead horses. In its most virulent form she will pursue her cause without concern for ethical considerations. . . [Y]ou cannot count on these people to Id at 6. represent their office. 
As noted above the workgroup is the primary working unit for the development of regulations in EPA. The goals of the workgroup are to (1) support the lead office in its design, technical, and analytical work; (2) identify and assess principal policy issues and options, especially those that are crossmedia; (3) resolve issues or elevate them for upper management's resolution; and (4) ensure the quality and completeness of regulatory packages.50 Members of the workgroup do not actually gather data and draft documents, tasks that are normally the responsibility of the lead office. Instead, they comment upon and critique documents that others draft.

Workgroup meetings, which occur regularly throughout the life cycle of a rule, are intended to "provide a forum for sharing expertise" and to help "resolve conflicts at the start, thus enhancing the quality of Steering Committee review." 51 Another unarticulated, but very real function of the workgroup is to bring together professionals with different perspectives to focus their attention on a regulatory problem and debate the appropriate ways to address that problem. Ideally, the interchange of perspectives helps achieve a synthesis that goes beyond the outlook or observations of any individual group member. Obviously, the likelihood that creative synergy will occur depends upon the level of energy that the workgroup members put into the effort.

Some workgroups are more active than others. For example, the workgroups that prepare the decision packages for the National Ambient Air Quality Standards meet very infrequently. Most of the real drafting and analytical work is done by informal groups composed of staffers from the Ambient Standards Branch and personnel from other parts of the agency who may or may not be members of the workgroup. Several of these informal groups may be assembled to work on different aspects of a single rule. Official workgroup meetings are called largely to ratify the work of the informal groups.

Workgroup meetings for the technology-based Effluent Guidelines and Limitations that the Office of Water Regulations and Standards promulgates follow a similar sporadic pattern. The workgroups for these standards are apparently not a high priority with the Office of Policy Analysis, because that office rarely sends a participant to the workgroup meetings until after the program office has nearly completed the drafting and analysis. The same apparently holds true for the representatives from OGC and the Office of Enforcement.

For all major and significant regulations, the first task of the workgroup is to draft a "development plan." The purpose of the development plan is to explain the need for the action; identify regulatory goals and objectives; present the major regulatory issues and alternatives; identify any policies, decision criteria, or other factors that will influence regulatory choices; and

50. The Workgroup, Fact Sheet 3, Regulation Management Series (EPA, May 1990 revision).

51. Procedures Memo at 4 (cited in note 41). 
present the work plan and resource requirements for developing the regulation. ${ }^{52}$ To the extent feasible at this early stage in the rule's evolution, the development plan is supposed to describe the environmental problem that the rule is to address, analyze the alternative approaches to solving the problem, and describe any foreseeable enforcement and implementation problems. The list of issues identified in the development plan may be amended as the workgroup progresses.

After the workgroup has completed the development plan, it must submit it to the Steering Committee for review and approval. Members of the Steering Committee are then expected to raise cross-media or other issues or alternatives not identified in the plan; inform the lead office of related activities underway in the Agency; encourage coordination of Agency resources, experience, and policies; and review the work plan and schedule to decide how the various offices will participate and whether they can meet the time and resource needs of the lead office. ${ }^{53}$ Although consensus in the Steering Committee is not necessary to approve a development plan, it must be approved by the committee's chairman. In practice, however, development plans are almost never disapproved. Like the start action request, the development plan appears to be a procedural device for informing other program offices and upper-level decisionmakers, rather than a substantive decisionmaking tool.

Once the development plan is completed, the workgroup's primary tasks are to make the hundreds of mini-policy decisions that go into the preparation of proposed and final rules and to oversee the production of the notice of proposed rulemaking, the regulatory impact analyses, the other technical support documents, and the "rulemaking package" that accompanies the rule through upper-level review. The workgroup's progress is documented in periodic "workgroup reports" to the Steering Committee. ${ }^{54}$ The reports describe the issues and options that the workgroup has addressed and resolved, the status of ongoing work, the likelihood of any delays, and any issues that the group has been unable to resolve and that must therefore be

52. Development Plans, Fact Sheet 4, Regulation Management Series (EPA, May 1990 revision). The development plan, drafted during the Reagan Administration, was originally required to discuss at least the following options: (1) no action; (2) alternatives to federal regulation, including market, judicial, or state or local regulatory mechanisms; and (3) alternatives within the scope of the action's legislative provision, including degree of control, effective compliance dates, and methods of ensuring compliance. Criteria and Guidelines Memo at 4 (cited in note 41). It is not clear that discussion of the first two options is mandatory under the current administration.

53. Development Plans, Fact Sheet 4 (cited in note 52).

54. During the mid-1980s, the workgroup was required to prepare a formal "Options Memorandum" for Steering Committee review (and for use in the now-defunct options selection/rejection process). That document was supposed to list the options, summarize the arguments for and against each option, and state the position of each office on each option. Telephone interview with Mr. Stuart Sessions, Acting Director, Regulatory Policy Division, Office of Policy Analysis, OPPE, EPA, May 29, 1984. This requirement theoretically provided an opportunity for upper-level decisionmakers on the Steering Committee or at higher levels to choose among the options at an early stage in the rule development process, rather than forcing them to concur or dissent in the option agreed upon by the workgroup. This process was abandoned at the end of the Reagan Administration. 
elevated to the Steering Committee. The project officer from the lead office submits the report to the office's Steering Committee representative for review; the other group members are supposed to brief their respective representatives on the issues that may arise at the Steering Committee meeting in which the report is discussed. The workgroup chairman typically attends the meeting to facilitate any discussion. The Steering Committee is supposed to focus on cross-media or other issues and alternatives not being considered by the workgroup and on resolving issues on which the workgroup could not reach consensus. Steering Committee concurrence in the report, which is documented in a closure memorandum, should ensure that issues resolved are not raised again later in the process.

The workgroup's final product is a rulemaking package that is composed of the workgroup's suggested draft of the proposed rule, the draft preliminary regulatory impact analysis, other required documents, and a decision memorandum outlining the options, detailing the pros and cons of each option, and explaining why and when each was rejected. The package must also estimate the resources required for implementing the rule, including enforcement plans and anticipated regional resource requirements.

2. The Interaction of Professional Perspectives in the Workgroup. It is at the workgroup level that the multiple rulemaking perspectives are corralled and brought to bear on scores of issues that must be resolved before a proposed or final rule may be presented to the administrator for approval. Each member of the group is aware of the fact that the other members bring to the workgroup meetings their own professional perspectives and the policy preferences of their institutional homes. Sometimes this baggage leads to creative compromises; sometimes it produces debilitating acrimony. Yet, since each member of the group knows that he or she will have to live with the others throughout the potentially protracted rulemaking process (and probably through similar rulemakings in the future), there is virtue in civility, and compromise is usually the order of the day. Few workgroup members relish the prospect of being shunned as a "bastard." 55

In EPA's early years, it was fairly easy to predict how the representative from a particular office would approach a particular issue. For example, the lead analyst from the Office of Policy Analysis was dependably wedded to the synoptic paradigm and predictably provided the brakes when the group appeared to be leaning toward options at the expensive end of the spectrum. ${ }^{56}$ The attorney from OGC was usually a bright and gung ho "Nader's Raiders-type" who pressed interventionist solutions to regulatory problems to a degree far beyond that mandated by a conservative reading of the statute. ${ }^{57}$ The lead office scientists and engineers were often similarly oriented toward command-and-control solutions to regulatory problems with

55. For the given definition of "bastard," see note 49.

56. See McGarity, Reinventing Rationality at 256-61 (cited in note 6).

57. See Harris \& Milkis, The Politics of Regulatory Change at 244 (cited in note 1). 
little regard for costs. ${ }^{58}$ The professionals from the enforcement office were interested in strict enforceability and were very skeptical of innovative approaches that would give regulatees greater flexibility to reach equivalent environmental protection at less cost.

The offices are not, however, as homogeneous as they once were. Workgroup representatives do not as often hew to the party line; indeed, it is not as clear that there is a party line to follow in some offices. Individual talents and personal philosophies can be more important than institutional loyalties. Nevertheless, while generalizations are less warranted today, each office pursues some of the broad goals of the regulation production process with more vigor than others, and different offices rank the agency's goals differently. Some determinants of agency policy seem relatively timeless and survive the arrivals and departures of individual agency officials.

To test this hypothesis, the author conducted a survey of twenty-six agency employees with extensive experience in the EPA rulemaking process. The survey listed ten agency goals and asked the respondents to rank on a scale from one-to-ten the vigor with which each office represented on the workgroup pursued each of the goals. The ten goals were

(1) Timeliness-producing rules in a timely fashion;

(2) Administrative Efficiency-writing rules in an efficient way that conserves agency resources;

(3) Scientific and Technical Credibility-producing rules with a sound scientific and technical basis;

(4) Allocative Efficiency-writing rules that are efficient from an overall societal perspective;

(5) Fidelity to Statute-implementing policies that are consistent with the agency's statutes;

(6) Judicial Review-producing rules capable of surviving judicial review;

(7) Political Review-producing rules that are capable of surviving political review;

(8) Enforceability-producing rules that can be implemented and enforced;

(9) Faimess-producing rules in a manner that fairly considers the views of all affected constituencies; and

(10) Multimedia Considerations-producing rules that reflect important multimedia considerations.

The offices the respondents were asked to rank included

(1) the relevant program office;

(2) the science advisory apparatus; 59

(3) the policy office (OPPE);

(4) the Office of General Counsel;

58. Id.

59. Although all respondents were asked about the scientific advisory apparatus, no representatives of the apparatus were surveyed. 
(5) the enforcement office; and

(6) the regional offices.

The respondents were promised anonymity and were encouraged to elaborate on their answers. The results for individual offices are reproduced in Table 1.

\section{TABLE 1}

Totals For All Programs*

\begin{tabular}{|c|c|c|c|c|c|c|}
\hline $\begin{array}{l}\text { Agency } \\
\text { Goals }\end{array}$ & $\begin{array}{c}\text { Program } \\
\text { Office }\end{array}$ & $\begin{array}{c}\text { Science } \\
\text { Advisory } \\
\text { Apparatus }\end{array}$ & $\begin{array}{l}\text { Office of } \\
P, P \& E\end{array}$ & $\begin{array}{l}\text { Office of } \\
\text { General } \\
\text { Counsel }\end{array}$ & $\begin{array}{c}\text { Office of } \\
\text { Enforcement }\end{array}$ & $\begin{array}{c}\text { Regional } \\
\text { Offices }\end{array}$ \\
\hline Timeliness & $\begin{array}{c}7.3 \\
2-10 \\
26\end{array}$ & $\begin{array}{c}4.3 \\
2-9 \\
20 \\
\end{array}$ & $\begin{array}{l}5.4 \\
3-9 \\
26 \\
\end{array}$ & $\begin{array}{l}5.3 \\
1-9 \\
26\end{array}$ & $\begin{array}{l}5.6 \\
3-9 \\
22 \\
\end{array}$ & $\begin{array}{l}6.7 \\
2-9 \\
20 \\
\end{array}$ \\
\hline $\begin{array}{l}\text { Administrative } \\
\text { Efficiency }\end{array}$ & $\begin{array}{c}7.2 \\
2-10 \\
26 \\
\end{array}$ & $\begin{array}{l}4.3 \\
0-9 \\
19 \\
\end{array}$ & $\begin{array}{c}5.4 \\
1-10 \\
26 \\
\end{array}$ & $\begin{array}{l}5.0 \\
1-9 \\
25 \\
\end{array}$ & $\begin{array}{l}5.0 \\
1-8 \\
20 \\
\end{array}$ & $\begin{array}{l}5.7 \\
1.9 \\
20 \\
\end{array}$ \\
\hline $\begin{array}{l}\text { Scientific and } \\
\text { Technical } \\
\text { Credibility }\end{array}$ & $\begin{array}{c}7.9 \\
3-10 \\
25 \\
\end{array}$ & $\begin{array}{c}9.1 \\
7-10 \\
21 \\
\end{array}$ & $\begin{array}{c}6.8 \\
2-10 \\
25 \\
\end{array}$ & $\begin{array}{l}6.9 \\
1.9 \\
25 \\
\end{array}$ & $\begin{array}{l}6.3 \\
2-8 \\
22 \\
\end{array}$ & \begin{tabular}{c|}
6.8 \\
$3-9$ \\
18 \\
\end{tabular} \\
\hline $\begin{array}{l}\text { Allocative } \\
\text { Efficiency }\end{array}$ & $\begin{array}{c}6.1 \\
3.10 \\
26\end{array}$ & $\begin{array}{l}4.9 \\
2-9 \\
19\end{array}$ & $\begin{array}{c}8.2 \\
5-10 \\
25\end{array}$ & $\begin{array}{l}5.3 \\
1-9 \\
26\end{array}$ & $\begin{array}{l}4.6 \\
1-9 \\
22\end{array}$ & $\begin{array}{l}6.1 \\
1-9 \\
20 \\
\end{array}$ \\
\hline $\begin{array}{l}\text { Fidelity to } \\
\text { Statute }\end{array}$ & $\begin{array}{c}7.8 \\
3-10 \\
25\end{array}$ & $\begin{array}{l}6.3 \\
3-9 \\
17 \\
\end{array}$ & $\begin{array}{c}6.1 \\
0-10 \\
25 \\
\end{array}$ & $\begin{array}{c}9.1 \\
5-10 \\
25\end{array}$ & $\begin{array}{c}8.2 \\
5-10 \\
21\end{array}$ & $\begin{array}{c}6.8 \\
4 \cdot 10 \\
19\end{array}$ \\
\hline $\begin{array}{l}\text { Judicial } \\
\text { Review }\end{array}$ & $\begin{array}{c}7.6 \\
2-10 \\
24\end{array}$ & $\begin{array}{l}5.6 \\
2-9 \\
18 \\
\end{array}$ & $\begin{array}{l}5.7 \\
2-8 \\
25 \\
\end{array}$ & $\begin{array}{c}9.5 \\
6-10 \\
24 \\
\end{array}$ & $\begin{array}{c}8.0 \\
5-10 \\
20 \\
\end{array}$ & $\begin{array}{l}5.9 \\
0-8 \\
18 \\
\end{array}$ \\
\hline $\begin{array}{l}\text { Political } \\
\text { Review }\end{array}$ & $\begin{array}{c}7.1 \\
4-10 \\
26 \\
\end{array}$ & $\begin{array}{l}4.4 \\
1-8 \\
18\end{array}$ & $\begin{array}{c}7.4 \\
4-10 \\
25 \\
\end{array}$ & $\begin{array}{c}6.8 \\
2-10 \\
25 \\
\end{array}$ & $\begin{array}{c}6.0 \\
2-10 \\
20 \\
\end{array}$ & $\begin{array}{c}5.9 \\
2.10 \\
19 \\
\end{array}$ \\
\hline Enforceability & $\begin{array}{c}7.1 \\
4-10 \\
26\end{array}$ & $\begin{array}{l}4.8 \\
2-8 \\
17\end{array}$ & $\begin{array}{c}5.5 \\
0.10 \\
26\end{array}$ & $\begin{array}{c}7.2 \\
4-10 \\
26\end{array}$ & $\begin{array}{c}9.0 \\
6-10 \\
22\end{array}$ & $\begin{array}{c}8.5 \\
6-10 \\
20 \\
\end{array}$ \\
\hline Fairness & $\begin{array}{c}7.5 \\
0-10 \\
26\end{array}$ & $\begin{array}{c}5.6 \\
0.10 \\
18\end{array}$ & $\begin{array}{c}6.9 \\
2-10 \\
25\end{array}$ & $\begin{array}{l}6.9 \\
2-9 \\
26\end{array}$ & $\begin{array}{l}6.2 \\
2-9 \\
21\end{array}$ & $\begin{array}{c}7.2 \\
4-10 \\
19\end{array}$ \\
\hline Multimedia & $\begin{array}{c}5.9 \\
0-10 \\
24\end{array}$ & $\begin{array}{c}7.5 \\
2-10 \\
15\end{array}$ & $\begin{array}{c}8.3 \\
6 \cdot 10 \\
24\end{array}$ & $\begin{array}{c}6.0 \\
0-10 \\
24\end{array}$ & $\begin{array}{c}5.8 \\
0.10 \\
21\end{array}$ & $\begin{array}{c}7.0 \\
3 \cdot 10 \\
18\end{array}$ \\
\hline
\end{tabular}

* Numbers in each box represent the average of all responses; the range of responses; and the total number of responses.

a. Timeliness. One important goal for all regulatory organizations is to produce regulations in a timely fashion. External reviewing institutions, like Congress and the courts, judge an agency by its ability to do what Congress tells it to do within a reasonable time, if not necessarily within the extremely ambitious deadlines to which Congress occasionally subjects EPA. Yet timeliness is not necessarily at the top of the agenda of every office within the agency. ${ }^{60}$ For example, the scientists in the Office of Research and Development and in the various scientific advisory committees are more committed to deliberation and less attuned to the program office's desire to

60. The first row of Table 1 suggests that timeliness is a much higher priority for the program office than for any other office. 
produce regulations by particular deadlines. ${ }^{61}$ Similarly, timeliness is not always at the top of OGC's agenda. ${ }^{62}$ Even assuming that every institutional actor strongly desires to promulgate agency rules in accordance with statutory or administratively established deadlines, the greater the number of institutional players, the greater the potential for delay.

The ever-present desirability of further research and monitoring can be used by the workgroup as a conflict-avoidance device when members fail to achieve compromise or when the workgroup seeks to avoid conflict with external groups. Conversely, delay can also be used for strategic purposes within the internal decisionmaking process to extract substantive concessions from offices that must account for delays. Because the program office is usually directly accountable for producing rules in a timely fashion, other offices, like OGC and OPPE, which are not as directly affected by delays, can threaten to devote more intensive review to aspects of a proposal to which they object as a lever to persuade the program office to delete or modify those aspects.

b. Administrative Efficiency. All of the offices within the agency have a putative interest in conserving the agency's scarce resources, but balkanized bureaucracies do not always behave in efficient ways. Each office's determination to preserve its own scarce rulemaking resources provides every incentive to shift burdensome aspects of individual rulemaking efforts to the other participating offices. It is easy enough, for example, for the regulatory analyst from OPPE to demand still another study of the effects of a regulation on a particular segment of the regulated industry if the expense of that study comes out of the program office's budget. Similarly, one office's priorities (shaped by its own concerns for administrative efficiency) may cause inefficiencies in other offices. For example, if putting a rule to one side until a more experienced attorney can review it is more efficient from OGC's standpoint, it may do so without regard to the possibility that the resulting delay thereby idles five staffers in the program office. Finally, not every office has the same regard for administrative efficiency as the program office whose resources are primarily at stake during the rulemaking process. ${ }^{63}$

61. It is apparent from Table 1 that the frequent participants in the rulemaking process surveyed believe that timeliness is a fairly high priority to the program office but not very important to the science advisory apparatus. See also Marcus, Promise and Performance at 111 (cited in note 1).

62. For example, OGC spent six years internally debating whether proposed rules for asbestos release from demolition activities would comport with the amendments to the Clean Air Act that followed the Supreme Court's holding in Adams Wrecking Co. v United States, 434 US 275 (1978). Although significant asbestos exposure was occurring at demolition sites, an EPA attorney acknowledged that "[t]he legal people spent a lot of time arguing about how to respond to the court case." Envir Rep Curr Dev (BNA) 2251 (April 20, 1984).

63. Table 1 suggests that the participants in the rulemaking process believe that administrative efficiency counts much more in the program office than in the other offices. This suggestion may be undermined somewhat, however, by the fact that far more of the respondents came from the program offices. It may well be that the participants felt obliged to rank administrative efficiency higher for purposes of the questionnaire than they do in real life decisionmaking. After all, no bureaucrat is likely to go on record as being in favor of administrative inefficiency. 
c. Scientific and Technical Credibility. One of the most devoutly aspired-to goals at EPA is scientific and technical credibility. According to the "transmission belt" theory of delegated regulation, the agency is supposed to be a reservoir of scientific and technical expertise. ${ }^{64}$ The legitimacy of the original delegation of decisionmaking power to regulatory agencies depends (in the minds of many observers) upon the agency's ability to produce rules with sound scientific and technical underpinnings. ${ }^{65}$ Yet when we pierce the agency's external veil, we quickly discover that few of the really important issues that it addresses in complex rulemakings are reducible to scientific facts and engineering judgments. It becomes readily apparent that scientific and technical credibility is not an all-encompassing goal for all offices that participate in the decisionmaking process. ${ }^{66}$

Scientific and technical credibility is less important than enforceability for the agency's enforcers. The agency's economists are seldom reluctant to challenge the program offices' models and interpretations, ${ }^{67}$ but their reason for doing so is usually a desire to produce less costly regulations, rather than to enhance the technical support for the program office's positions. Although scientific and technical credibility is important to the lawyers in OGC, arriving at the "truth" in an absolute sense is not nearly so critical for them as conveying the perception that the agency has conscientiously considered all of the credible points of view. The reviewing courts do not demand scientific accuracy where uncertainties preclude firm conclusions, ${ }^{68}$ but they do require the agency to consider the relevant information and explain why it accepted some studies and rejected others. ${ }^{69}$ The attorneys sometimes resist candor, especially when it might undercut the technical basis for the option that the agency adopted. ${ }^{70}$

d. Allocative Efficiency. Regulatory agencies have long been accused of placing overall societal efficiency on a lower plane than other programmatic goals. Economists in academia and government believe that allocative efficiency is best achieved when the benefits of a regulation outweigh the costs

64. See Richard B. Stewart, The Reformation of American Administrative Law, 88 Harv L Rev 1669, 1684 (1975).

65. See, for example, Joseph D. Rosen, Much Ado About Alar, 7 Issues Sci \& Tech 85 (Fall 1990).

66. Table 1 indicates that while scientific and technical credibility is high on everyone's list, it is a much higher priority for the program office and the scientific advisory apparatus (the most vigorously pursued goal by both offices) than the other offices that participate in the process.

67. See EPA Deputy on Verge of Crucial Policy Decision, Clearing Major RCRA Rule, 11 Inside EPA 12 (Jan 12, 1990) (detailing a disagreement between EPA's Office of Solid Waste and OPPE over the appropriate assumptions underlying a proposed model for predicting how much a waste dissipates as it travels through groundwater).

68. Ethyl Corp. $v E P A, 541$ F2d 1, 28 (DC Cir 1976) ("Where a statute is precautionary in nature, the evidence difficult to come by, uncertain, or conflicting because it is on the frontiers of scientific knowledge[,] we will not demand rigorous proof of cause and effect.") (court upholds lead phasedown regulations); Industrial Union Dept., AFL-CIO v Hodgson, 499 F2d 467, 477 (DC Cir 1974) (court upholds Occupational Safety and Health Administration's standard for asbestos).

69. Portland Cement Co. v Ruckelshaus, 486 F2d 375, 398 (DC Cir 1973).

70. See Landy, Roberts \& Thomas, Asking the Wrong Questions at 79 (cited in note 1). 
of compliance. ${ }^{71}$ Yet many offices in EPA undeniably fail to assign allocative efficiency a high priority for a variety of reasons. The scientific advisory apparatus does not pay particularly close attention to the costs of regulations, although cost considerations occasionally shade the scientists' views of the merits of regulatory proposals. ${ }^{72}$ Similarly, the enforcement office's attention to the cost of regulations focuses mainly upon the incentives that expensive rules provide for regulatees to avoid complying with them. Although EPA attorneys are not always strong proponents of allocative efficiency, their desire to see the agency's regulations survive judicial review sometimes causes them to advocate cost-effective solutions to regulatory problems. ${ }^{73}$

The economists in OPPE are the agency's strongest advocates for efficiency. ${ }^{74}$ They are constantly urging workgroup members to count the costs of the regulatory options. ${ }^{75}$ Although the analysts have occasionally pressed for more stringent regulatory options, ${ }^{76}$ much of the time the economists' concern for allocative efficiency translates rather easily into an uninhibited demand for less stringent regulations. ${ }^{77}$ This tendency leads other participants in the decisionmaking process to question whether allocative efficiency is a goal worth vigorously pursuing.

e. Fidelity to Statute. Since every regulatory agency must point to a statute for its authority to regulate private conduct, implementing policies that are consistent with its statutes should rank high among EPA's goals. Yet, even this unobjectionable goal is pursued more vigorously by some offices than others. The matter is complicated somewhat by the fact that Congress

71. See Allen V. Kneese \& Charles L. Schultze, Pollution Prices and Public Policy: A Study Sponsored Jointly by Resources for the Future, Inc. and the Brookings Institution (Brookings Inst, 1975); Lester B. Lave, The Strategy of Social Regulation: Decision Frameworks for Policy 3-4 (Brookings Inst, 1981).

72. See text at note 58 .

73. See Landy, Roberts \& Thomas, Asking the Wrong Questions at 11 (cited in note 1).

74. See McGarity, Reinventing Rationality at 258-59 (cited in note 6); Landy, Roberts \& Thomas, Asking the Wrong Questions at 11 (cited in note 1). EPA has prepared formal Regulatory Impact Analysis Guidelines for the program offices and their consultants. Guidelines for Performing Regulatory Impact Analysis (EPA, 1983). These guidelines reveal a lot about the OPPE's viewpoint. The guidelines adopt a strong quantitative approach to assessing the costs and benefits of EPA regulations. See McGarity, Reinventing Rationality at 171-74 (cited in note 6).

75. Table 1 indicates both that allocative efficiency is by far one of the highest goals of OPPE in the minds of frequent participants in the internal rulemaking process, and that allocative efficiency matters much more to that office than to the other offices.

76. For example, an analyst from OPPE provided much of the information that EPA used to justify its stringent lead phasedown regulation. The agency also relied on studies undertaken by that office to justify not relaxing the ambient air quality standard for particulate matter. McGarity, Reinventing Rationality at chs 3-4 (cited in note 6).

77. For example, when EPA was deciding whether to amend the national ambient air quality standard for photochemical oxidants, the economists in OPPE pressed so hard for a reduced standard that they helped the White House Regulatory Analysis Review Group prepare its assault on the program office's proposed regulation. Landy, Roberts \& Thomas, Asking the Wrong Questions at 71 72 (cited in note 1 ). 
often uses such vague language in its statutes that it is difficult to determine whether one or another regulatory option will advance the goal of fidelity. ${ }^{78}$

OGC plays a dominant role in ensuring that the agency writes rules that are consistent with the agency's statutes. ${ }^{79}$ Even when, as is often the case, the agency's statute gives it some leeway to choose among several regulatory options, the general counsel's role is to tell the program officer which of the options are clearly within the realm of the agency's authority and which are close calls. The representatives from other offices in the workgroup may ignore OGC's pronouncements only at a fairly high risk of having the entire matter remanded by upper-level policymakers during Red Border Review (see below), where the general counsel's interpretation of the statute is rarely questioned.

In addition to its role as statutory interpreter, OGC plays a quality control role. To ensure that rules survive substantive judicial review, the agency's attorneys often delve into the technical, economic, and legal underpinnings of the rules, and the attorneys seldom feel confined to pristine questions of statutory interpretation. Since many of the important and controversial science and policy disputes that arise in EPA rulemaking are ultimately resolvable only by reference to policies that originate in the agency's statutes, the attorney's role may range broadly into areas that other members consider to be within their own professional bailiwicks. This bifurcated role for OGC can thus lead to friction with the other offices and to the aggrandizement of institutional power of lawyers with their own ideas about appropriate regulatory policy.

OPPE rarely allows deference to OGC's interpretation of congressional policy directives to stand in the way of its pursuit of economically efficient standards. For example, even though the courts have held that the Clean Air Act forbids cost considerations in promulgating national ambient air quality standards, ${ }^{80}$ the policy office constantly raises cost considerations in workgroup and in other high-level, intra-agency forums. Indeed one highly placed official in that office during the second Ruckelshaus administration said that it was important to document the costs of achieving the national ambient air quality standards to "rub everyone's nose in the senselessness of the statute." 81

78. See Colin S. Diver, Statutory Interpretation in the Administrative Slate, 133 U Pa L Rev 549, 55559 (1985); William N. Eskridge, Jr. \& Philip P. Frickey, Statutory Interpretation as Practical Reasoning, 42 Stan L Rev 321,335 (1990).

79. Table 1 indicates that the participants in the rulemaking process regard fidelity of the statute as the second most intensely pursued goal in OGC. The table also shows that the program offices and the Office of Enforcement regard statute fidelity highly as well.

80. American Petroleum Institute v Costle, 665 F2d 1176, 1185 (DC Cir 1981) (court upholds EPA's revised national ambient air quality standards for photochemical oxidants); Lead Industries Ass'n v EPA, 647 F2d 1130 (DC Cir) (court upholds EPA's national ambient air quality standards for lead).

81. See also Landy, Roberts \& Thomas, Asking the Wrong Questions at 106 (cited in note 1) (detailing the dispute between the policy office and the program office over the costs of regulations for the disposal of hazardous wastes). 
The science advisory apparatus, while providing supposedly scientific advice, can also show contempt for statutory policy prescriptions. For example, when EPA was revising the national ambient air quality standards for photochemical oxidants, James Whittenberger, a professor of physiology at the Harvard School of Public Health and chairman of a Science Advisory Board subcommittee, argued strongly that the scientists should offer their advice on what was an acceptable risk and what was an adequate margin of safety. Even though specifically instructed that economic considerations were not supposed to play a role in the decisionmaking process, Whittenberger remarked: "In spite of what the legal requirements are, it seems to me that eventually we are going to have to take economics much more into consideration." 82 Thus, even scientists can place their views of appropriate regulatory policy ahead of the policies articulated by Congress.

f. Judicial Review. Since the courts have the power to set aside agency rules that are not in accordance with agency statutes, or that are otherwise arbitrary and capricious, all institutional subunits have an interest in producing rules that are capable of surviving judicial review. Although, as previously discussed, OGC is primarily responsible for ensuring that the agency is interpreting its statutes correctly, all of the offices are responsible for ensuring that the agency's regulations survive arbitrary and capricious review. A remand means more work and wasted time. Still, some offices view this goal more seriously than others.

Obviously, OGC regards surviving judicial review as a primary goal. When the agency suffers a judicial remand, OGC is often blamed. The program offices and the Office of Enforcement also assign a high priority to successful judicial review. 83 The science advisory apparatus, by contrast, cares more about scientific correctness than about whether three judges think that the agency has reached a good result. OPPE is similarly much less concerned about pleasing the judges than about writing rules that provide the greatest benefits to society at the least cost.

g. Political Review. A rule that is capable of surviving judicial scrutiny may not survive political review in institutions (primarily OMB and Congress) that have the power to impede the rulemaking process. Again, the fact that all of the offices have a stake in the successful survival of a regulation does not mean that they all pursue this goal with equal vigor. The program offices must be highly interested in the views of influential members of Congress and White House officials. The views of congressional staffers and of the

82. Id at 53. The Secretary to the Science Advisory Board also became involved in the debate between the program office and the policy office over the proper level of the national ambient air quality standard for photochemical oxidants. Cost considerations persuaded him that the agency should not take a conservative approach to setting the standard. Id at 70. He took this position despite the fact that the statute bars cost considerations.

83. Table 1 reveals that successful judicial review is a high priority in the program office, OGC, and the Office of Enforcement, but is much less important in the science advisory apparatus, OPPE, and the regional offices. 
economists and analysts in OMB do not matter very much to the science advisory apparatus. The analysts in OPPE have little regard for the interest group-oriented political concerns of congressional staffers. They are much more attentive to the cost-sensitive concerns of OMB, but often regard OMB input (which they believe is more often interest group-oriented than analytical) cautiously. Finally, the regional offices are very concerned about how EPA programs are perceived at the local political level. Systematic political missteps on the local level can quickly translate into serious political problems at the national level. In addition, if the regions send inconsistent signals to regulatees and the public, EPA as a whole may suffer politically. ${ }^{84}$

h. Enforceability. Producing rules that are easily implemented and enforced is ultimately the responsibility of program offices, but the entity with the greatest concern for enforceability is, of course, the Office of Enforcement. The professionals in that office are proud of their familiarity with the "real world beyond the Beltway" where some of the best laid plans of the agency's scientists, engineers, economists, and attorneys go badly awry. Perhaps because attorneys usually see implementation as a matter of writing and enforcing rules, enforceability is also a high priority for OGC. ${ }^{85}$ Although the Office of Enforcement does not always send representatives to workgroup meetings, when they do attend, they come armed with a healthy skepticism about innovative new approaches that are supposed to save overall costs by increasing the flexibility of regulatees. For example, when many other offices in the agency became enthusiastic about the "bubble" policy in the late 1970s, the Office of Enforcement was justifiably worried that companies would trade enforceable emissions (for example, monitorable emissions through a stack) for unenforceable emissions (for example, promises to wet down streets and coal piles on a weekly basis). ${ }^{86}$ In retrospect, the Enforcement Office's skepticism was warranted; many of the early bubbles were of this unattractive variety. Sometimes the Enforcement Office representatives argue for stringent regulations simply to allow the agency to negotiate from a position of strength in subsequent enforcement actions where the real limitations on the conduct of regulatees are established. ${ }^{87}$

i. Faimess. Like other regulatory agencies in a society of limited government, EPA must concern itself with the extent to which the public

84. See Landy, Roberts \& Thomas, Asking the Wrong Questions at 240 (cited in note 1) (recounting a dispute between headquarters staff and regional offices about the definition of "reasonably available control technology" under part D of the Clean Air Act).

85. See id at 123 (relating OGC's opposition to the use of "best engineering judgment" as the test for permitting hazardous waste disposal facilities on the ground that it was too vague to be implemented consistently).

86. See id at 216-18. Interestingly, for reasons that are not very clear, OGC supported the policy office in this debate. Id.

87. See Brian J. Cook, Bureaucratic Politics and Regulatory Reform: The EPA and Emissions Trading (Greenwood Press, 1988). 
perceives its decisionmaking procedures as fair. Yet fairness is not an especially significant goal of any of the headquarters' offices. The attorneys in OGC have received training in principles of due process that capture fairness in a formal sense, and that office insists that the agency adhere strictly to the requirements of the Administrative Procedure Act. ${ }^{88}$ But it does not often insist that the agency go beyond the minimum criteria of that statute unless required by another statute. However, because the regional offices have direct hands-on experience with companies and people who are affected by EPA regulations, they are inclined to be very concerned about public perceptions of fairness. ${ }^{89}$ The regional office staffs are more inclined than headquarters' personnel to meet informally with affected regulatees and beneficiary groups to discuss particular criticisms of EPA proposals.

j. Multimedia Considerations. Although EPA has retained its programmatic divisions, the agency has become increasingly convinced that the focus of most rulemaking initiatives on controlling pollution in only a single medium has not sufficiently taken into account cross-media aspects of pollution and pollution control technologies. If a regulation promulgated under the Clean Air Act accomplishes no more than transferring residuals from the air to the water or soil, it is not at all clear that the environment has benefitted. Similarly, it is unsettling to learn that publicly owned sewage treatment works are large contributors to toxic air pollution. ${ }^{90}$ The agency's leadership has often worried that decisions made by one program with respect to a specific chemical substance could narrow the range of options available to other programs to deal with the same chemical. In 1987 the agency launched a "toxics integration project" to explore a cross-media approach to chemical regulation, ${ }^{91}$ and in 1988 it created a separate Office of Pollution Prevention with a cross-media focus. ${ }^{92}$

Because the agency's leadership has recently sent a strong message to lower-level officials that multimedia considerations are important, they are putatively high on the agendas of all of the offices in the agency. Nevertheless, it seems clear that single-medium program offices do not spend much time thinking about the effects of their regulations on media that are

88. On Table 1, fairness ranks fourth on the list of goals for OGC.

89. See Landy, Roberts \& Thomas, Asking the Wrong Questions at 211 (cited in note 1).

90. Raymond C. Loehr \& Calvin H. Ward, Waste Treatment Practices and Cross-Media Transfer of Pollutants, in Cross-Media Approaches to Pollution Control (Natl Acad Sci/Natl Res Council, 1987); PPE Eyes In-Plant Steam Stripping to Cut Voc Air Emissions from POTW's, 7 Inside EPA 1 (May 2, 1986) (alluding to doubts about EPA's authority under the Clean Water Act to regulate air emissions from publicly owned sewage treatment plants); Small Business Standards Disputed in Rulemaking for Chemical Plants, 17 Envir Rptr (BNA) 36 (May 9, 1986) (same).

91. See Alm Chooses Butadiene and Cadmium for Trial Toxics Integration Project, 4 Inside EPA 11 (Dec 23, 1983) (reporting Deputy Administrator Alm's decision to apply an integrated cross-media approach to two chemicals as models for the toxics integration project).

92. See Envir Rptr (BNA) 384 (July 22, 1988). Since most of the respondents were from the program offices, this evaluation is especially significant. 
regulated by other offices, ${ }^{93}$ except in relatively rare cases in which one office recognizes in advance that a proposal from another office may force the first office to regulate more or less stringently. ${ }^{94}$ OPPE is currently the agency's principal exponent of multimedia approaches to regulatory decisionmaking. ${ }^{95}$ OGC also has an important role to play in implementing multimedia approaches, because it is the ultimate interpreter of the agency's statutes, including the gap-filling Toxic Substances Control Act. ${ }^{96}$

3. Workgroup Deliberations. One desideratum of the workgroup approach is to inspire creative collective thinking about innovative regulatory alternatives. The lead office has the first opportunity to identify options, based upon the judgment and prior experience of its staff scientists and engineers. Innovative options often arise out of interchanges between the technical lead office staff and the regulatory analysts in the lead office. In the Office of Solid Waste, for example, the regulatory analysts have pressed the technical staff to make more explicit the use of risk-assessment techniques and benefits analysis, and to allow for greater discretion at the permit stage to ensure that hazardous waste disposal standards afford maximum flexibility for considerations of location, nature of waste, and other site-specific concerns. ${ }^{97}$ The other offices represented on the workgroup occasionally suggest additional options, but in most cases the lead office's technical judgment and experience appear to dominate the options-identification effort. In practice, the workgroup members are more useful in reviewing the options that have already been identified than in identifying fresh options.

Two leading goals of the workgroup are to arrive at a consensus on the analysis of various options and, if possible, to agree upon a single option to recommend to upper-level decisionmakers. The members of the workgroup feel some pressure from their superiors to reach consensus. Busy decisionmakers usually want to know why the workgroup members were unable to work things out on their own.

The workgroup process offers innumerable opportunities for members to apply their expertise to regulatory problems and to use the tools that are available to them to steer the group toward each member's preferred alternatives. If one representative on the workgroup can legitimately claim greater expertise or experience in an area addressed by the rule, other members are likely to defer to that member. Nevertheless, the cardinal rule of

93. Table 1 indicates that the interviewers believed that OPPE pursued multimedia considerations more vigorously than any of the other nine goals, though only slightly more vigorously than allocative efficiency.

94. See Air, Drinking Water Offices Clash over Regulation of Organic Chemicals, 5 Inside EPA 1 (March $16,1984)$

95. Table 1 indicates that multimedia considerations is the second most vigorously pursued of the ten identified goals.

96. 15 USC $\S \$ 2601-2671$ (1982).

97. See McGarity, Reinventing Rationality at 254-55 (cited in note 6). 
the seasoned workgroup participant is, "trust, but verify."98 Even the group's expert is expected to provide data and analysis to support his or her position.

Since resources are always in short supply, an office that can contribute resources to the process can thereby increase its influence. For example, although the program office staff ordinarily drafts the important rulemaking documents, any member of the workgroup can volunteer to draft portions of a document, and such overtures are rarely refused. While all of the other members will have ample opportunity to comment upon and suggest changes to the drafted language, the volunteer has an opportunity to shape the document in subtle ways that can heavily influence the direction that the rulemaking initiative takes. Similarly, a member who volunteers to collect and analyze information on a particular issue has a significant opportunity through subtle interpretations, assumptions, and information display techniques to shape how the rest of the members perceive that data.

Precedent and the search for consistency can also shape the workgroup's output. If one member can document a prior occasion in which the agency resolved an issue in a particular way, the group is likely to adhere to the precedent. Thus, participants with significant experience in the agency can be very influential on some workgroups.

Although the representative from each office comes to the meetings with strong preconceptions and professional biases as well as institutional positions to defend, a good deal of "horse trading" usually takes place during workgroup meetings. For example, the representative from the policy office may be willing to retreat from his or her cost concerns if the representatives from the program and enforcement offices are willing to accept a greater degree of flexibility in crafting the regulatory requirements. These none-toosubtle tradeoffs are essential if the group is to reach the much desired consensus at the end of its deliberations.

Workgroups also provide many opportunities for strategic alliances among representatives who share the same approach toward resolving important issues. Although consensus is the goal, there is strength in numbers, and a large enough faction can bring around the rest of the members. Strategic game playing is limited, however, by the knowledge that the holders of minority positions can always elevate the dispute to the Steering Committee level and beyond.

Perhaps the most powerful tool available to a workgroup member is the threat of delay. The project officer from the lead office (who is also the chairman of the workgroup) is responsible for bringing the initiative to fruition in accordance with a prearranged time schedule that is documented by the milestones in the action tracking system. It is very difficult for the project officer to decline legitimate requests for more information or for time to study complicated data and analyses more thoroughly. Yet it is equally difficult to know whether the workgroup member requesting additional time

98. Diamond, Practical Aspects of Workgroup Operations at 9 (cited in note 48). 
is doing so out of genuine concern for the integrity of the decision or out of a desire subtly to extract concessions out of the lead office. Since OGC and OPPE do not feel especially bound by program office calendars, they most frequently employ this tactic.

A determined project officer can attempt to steamroller a regulation through the process by setting unrealistic deadlines for comments from the other offices, by meeting at inconvenient times, and by ignoring the input of other offices. But this tactic may backfire at the Steering Committee stage when the representative of one of the other offices (often at the request of that office's representative on the workgroup) objects to the workgroup's proposal. As with the workgroup, the goal of the Steering Committee is to reach consensus, and decision packages can be remanded to workgroups to meet the concerns of the objecting Steering Committee members.

In assembling the technical support for an important rule, program offices frequently identify those controversial scientific issues the proper resolution of which is critical to the substantive outcome of the rulemaking. When the workgroup agrees that the issue is scientific in nature and is likely to be both controversial and outcome-determinative, it may refer the matter to the Science Advisory Board for advice. Staffed by the Office of Research and Development, the Science Advisory Board is composed entirely of prestigious academic, industry, and environmental group scientists who have agreed to offer scientific input on critical scientific issues that the agency faces. Some programs have their own outside scientific advisory groups established by statute. For example, the Clean Air Scientific Advisory Committee reviews the technical support documents for all of the national ambient air quality standards, and the Scientific Advisory Panel in the Office of Pesticides Programs reviews all pesticides rules and potential pesticide cancellation actions. Obviously, some care must be taken in drafting the questions for these committees to avoid receiving policy prescriptions, rather than scientific advice. In practice, it is very difficult to confine the committees to "pure" scientific issues, especially in those committees that are chartered to review the scientific aspects of all of a program's regulations. The advisory committees usually prepare detailed written reports that are incorporated into the decision packages and the rulemaking records. Although the committees' pronouncements on scientific questions are not binding on the agency, the workgroup must be prepared to explain any significant disagreements that it has with its scientific advisors.

\section{Steering Committee Review}

The rulemaking packages for major and significant rules are sent to the Steering Committee for final review. The Steering Committee reviews all major rules and many significant rules at a regular meeting. ${ }^{99}$ Members of the

99. Some significant rules may be disposed of through the "consent calendar." Procedures Memo at 8 (cited in note 41 ). 
Steering Committee rarely suggest options that have not already been identified at the workgroup level. The Steering Committee is more a reviewing body than an institution for developing innovative solutions to regulatory problems. The Steering Committee meeting on a rulemaking package can be a forum for debating issues that have not been resolved in the workgroup. In addition, one of the committee's responsibilities is to identify significant issues for upper-level management, whether or not the workgroup has reached consensus on those issues. The closure memorandum drafted by the Steering Committee chairman documents the committee's resolution of outstanding issues. ${ }^{100}$

A recently adopted alternative to Steering Committee review for finished workgroup products is the Workgroup Closure Meeting. This meeting provides a forum for confirming that the workgroup has resolved as many outstanding issues as possible and has clearly defined the remaining issues. The Workgroup Closure Meeting is attended by the regular workgroup participants, but is chaired by the chairman of the Steering Committee. Each participant is supposed to come to the meeting prepared to state the position of his or her assistant administrator. A closure memorandum is prepared to document the positions of the respective offices. The assistant administrators are theoretically bound to the documented positions taken by their representatives in the meeting.

\section{Red Border Review}

After the Steering Committee has concluded its deliberations, the package is cleared for "Red Border Review." This process is the formal review procedure whereby senior management (usually assistant and regional administrators and the general counsel) reviews and approves regulatory packages for all rules (including minor rules) before they are presented to the administrator. The review always includes the general counsel and the Assistant Administrator for Policy, Planning and Evaluation, and other assistant administrators for offices that were represented on the workgroup. Usually at this point the parties to any remaining disputes attempt to resolve as many open questions as possible in informal meetings, often at the assistant administrator level. Reviewing offices may make written comments and transmit them to the lead office. After responding to relevant comments, the lead office prepares the package for transmittal to the administrator and OMB.

\section{E. Final Rules}

The agency procedures for responding to public comments on a proposed rule and for preparing the final rule and its accompanying regulatory package

100. EPA has experienced a few problems with differing interpretations of closure memoranda. On some occasions, each side to a debate has read the closure memorandum to seal a victory for its point of view. On other occasions, one office has disagreed with the closure memorandum's interpretation of the outcome of the meeting. 
are virtually identical to the procedures governing the preparation of the initial rulemaking and regulatory analysis documents. The project officer in the lead office is responsible for assembling the public comments and breaking them down by issue as far as possible. The agency sometimes hires contractors to read and separate the comments. The comments are then distributed to the personnel who drafted the portions of the documents that the comments addressed. After the various offices have had a sufficient opportunity to respond individually, the project officer calls a workgroup meeting to discuss how the agency as a whole should respond to the comments. The workgroup again attempts to reach consensus on the changes that should be made in light of the public comments. The workgroup's recommendations and dissenting opinions are then forwarded to the Steering Committee and from there sent to Red Border Review.

\section{$\mathrm{V}$}

\section{Structural Models for the Internal Decisionmaking Process}

On paper, EPA has currently adopted a relatively pristine version of the team model for most of its rulemaking initiatives. The workgroup is the functional staff-level team, and the Steering Committee is the high-level management team. Although the team model is the most familiar decisionmaking model in the federal government, it is by no means the only one available. Other models offer some advantages over the team model, but they have disadvantages as well. Many agencies and departments have adopted different models in different decisionmaking contexts, and EPA itself has informally resorted to alternative models when conditions dictated. The remainder of this paper will identify and analyze some of the competing models available to EPA and offer some observations about when one model might be superior to the others.

\section{A. The Team Model}

The basic decisionmaking unit under the team approach is the team composed of representatives from all of the institutional subunits within the agency that have an interest in the outcome of the rulemaking process. The team meets periodically to discuss regulatory options, to examine problem areas, to respond to requests of upper-level decisionmakers, and to resolve disputes among team members. Although a single office usually has overall responsibility for the rulemaking effort, the group can delegate tasks to individual members or small subcommittees. All team members receive copies of pertinent decisionmaking documents for review and comment. All are supposed to be co-equal partners in pursuit of the common goal of promulgating a rule that will survive internal and external review. Team members usually feel pressure from other participants and from their own superiors to reach consensus on important issues.

As we have seen, the team approach has several advantages over other models, the most significant of which is its capacity to bring multiple 
professional perspectives to bear on issues that arise in complex rulemakings. The team model allows the agency to base its decision on a wide range of information and analysis from multiple sources. It may also facilitate innovative, cross-disciplinary thinking about novel options for solving regulatory problems. The very concept of a team connotes harmony and the pursuit of common goals that may take the adversarial edge off of interactions among persons with divergent professional perspectives and policy preferences.

Because it incorporates all of the relevant institutional actors into a single decisionmaking entity, the team model has the potential to avoid timeconsuming delays when the final staff product is reviewed by upper-level decisionmakers. Because the assistant administrators are represented on the team, they are expected to raise their concerns at the team level and not at higher levels where the only option is to go back to the drawing board. At the same time, the pressure for consensus in the team meetings relieves upperlevel decisionmakers of the necessity of attending lengthy meetings in which minor issues are debated exhaustively. The team model thus allows busy decisionmakers to delegate a good deal of the decisionmaking authority to agency staff, secure in the knowledge that most important issues will either be resolved by the team in an acceptable manner or elevated to the top levels of the hierarchy.

Finally, the team model has the capacity to provide the integration of programs that a multimedia approach to pollution control demands. If the agency insists that each of the program offices assign a person the responsibility of keeping track of how the team's regulatory options affect the environmental medium overseen by that office, the agency is more likely to adopt an option that has the most beneficial overall impact on the environment.

The team model also has disadvantages. The foregoing description of the team model at EPA suggests that it can be very resource intensive and time consuming. The agency must maintain a staff of experts from a variety of disciplines and allow them sufficient time to interact on teams. Every member of the team must be educated on the essential issues and encouraged to make his or her contribution. The greater the number of institutional actors that must be consulted, persuaded, and cajoled, the longer it takes to get a plan approved. This is especially true if the team model operates sequentially without periodic meetings to encourage communication and put everyone's position on record. If every office must see the input of every other office before it is willing to sign off on a plan, the process can degenerate into a never-ending loop. In addition, as we have seen, when delay can be used for strategic purposes, more delays are likely. ${ }^{101}$

The multiplicity of experts from different offices also presents problems of accountability. In the agency's hierarchy, the members of the team do not

101. See Marcus, Promise and Performance at 25 (cited in note 1); discussion at part IVB2a. 
report to the team chairman. In the real bureaucratic world, where rewards are bestowed and punishments meted out, the team representative is accountable only to his or her own boss. If a team member fails to honor a commitment within the agreed-upon time frame, the workgroup chairman may complain to the member's boss, but the most realistic alternative is to proceed ahead without the foot-dragger's input. Within EPA this latter option may result in delays later in the process when upper-level officials from the sluggard's office raise objections that the team member should have raised during the initial review process.

The pressure toward consensus that is one of the advantages of the team approach may also be a disadvantage, because it has the potential to steer the group away from the best solutions. Since few employees desire to be placed in the "bastard" category, they may compromise too readily on important points, thereby depriving upper-level decisionmakers of the opportunity to determine which resolution is best.

Worse, team members are susceptible to a mind-numbing malady that Professor Janis calls "groupthink." According to Janis, "members of any small cohesive group tend to maintain esprit de corps by unconsciously developing a number of shared illusions and related norms that interfere with critical thinking and reality testing." 102 The team model can effectively line up all of the relevant institutional actors behind a single recommendation to the decisionmaker, leaving the decisionmaker with only two realistic optionsto accept the staff recommendation or to remand the matter to the staff. The net result may be that "[w]hen compromise positions reach a high-level executive in a form that suggests a unified, consensual judgment, they can give the ultimate decisionmaker a false sense of security; the policymaker receiving the watered-down proposals may lack an awareness of the potential problems buried within the recommendations." 103

Perhaps the most significant disadvantage of the team model is its potential to shift the locus of policymaking from upper-level political appointees to career staff. This shift can happen in several ways. First, a critical aspect of bureaucratic decisionmaking is the function of initially identifying the universe of possible options to solve the problem and the continuing process of narrowing those options to the one that the agency ultimately selects. The team model, especially as practiced at EPA, has a strong tendency to lodge this crucial aspect of rulemaking discretion at lower levels in the agency hierarchy. For example, one of the articulated goals of the EPA workgroup is to reach consensus on the proposed and final rules. Yet if the workgroup reaches consensus and that consensus is maintained (as is usually the case for important issues) throughout Steering Committee and Red Border Review, there is very little for the ultimate decisionmaker (the

102. Irving Lester Janis, Victims of Groupthink: A Psychological Study of Foreign Policy Decisions and Fiascoes 35-36 (Houghton, Mifflin, 1972).

103. George C. Edwards, III \& Ira Sharkansky, The Policy Predicament: Making and Implementing Public Policy 128 (Witt Freeman, 1978). 
administrator) to decide. If he or she asks for an options memorandum at this late stage in the rulemaking process, the result is likely to be a perfunctory effort in which the staff's preferred option is sandwiched between two impractical red herrings. The only real option for the decisionmaker is to remand the entire matter to the staff with orders to start over. And even that is not a realistic option for rules that must be written by statutory or courtimposed deadlines. In reality, the important decisions (including significant policy determinations) are often made by the staff.

A second way in which the team model shifts decisionmaking discretion from high levels to low levels stems from the policy-dominated character of much scientific decisionmaking in modern regulatory agencies like EPA. While the concept of an expert agency demands that the staff be given a wide degree of discretion to resolve scientific and technical questions, most of the controversial issues that arise in environmental rulemaking are mixed questions of science and policy that are typically stated in scientific terms, but are resolvable only as policy questions. ${ }^{104}$ If the staff professionals are allowed to resolve these science/policy issues, they may apply different policies than those preferred by upper-level decisionmakers. The team model allows lower-level staff to disguise policymaking behind the veneer of professional consensus.

A third way in which the team model can shift the locus of power lies in that which might be termed "policy inertia." To the extent that teams possess the subtle policymaking discretion described, they will tend to pursue the same policies that they have always followed. We have seen that one of the strongest arguments in workgroup meetings for pursuing a particular option or adopting a particular policy is that the agency has done it that way in the past. This inertial force resists rapid shifts in agency policy. Even if one or more of the team members detect a change in policy at upper levels in the agency, the pressure for reaching a consensus dampens their enthusiasm and reduces the extent to which the policy change can be implemented through the workgroup vehicle. In the absence of direct appeals to upper-level decisionmakers, where the new policy can be made more explicit, the team is likely to pursue old policies.

At the extreme, the team approach can produce such a strong consensus among lower-level team members that it becomes a "renegade team" that attempts to impose its views of correct policy upon politically accountable upper-level decisionmakers through leaks to the press and other techniques of sabotage. During the Reagan years, OSHA teams frequently wrote policyoriented memoranda to upper-level decisionmaking entities and simultaneously leaked them to the press. Convinced that their advice would never be heeded by anti-interventionist, upper-level decisionmakers, the teams made their case to other policymakers. Thus, critics on Capitol Hill were armed for their attacks on the agency by the very teams to which the

104. See Thomas O. McGarity, Substantive and Procedural Discretion in Administrative Resolution of Science Policy Questions: Regulating Carcinogens in EPA and OSHA, 67 Georgetown L J 729 (1979). 
agency had entrusted the preparation of the agency's support documents. ${ }^{105}$ The phenomenon so irritated the assistant secretary for OSHA that he abolished a rather intricate team system that he had only recently (and with much fanfare) established, and replaced it with a more hierarchical approach that lodged most decisionmaking authority in faithful middle-level appointees. ${ }^{106}$ The power of career bureaucrats to co-opt political appointees bent on re-orienting bureaucratic norms is well known, but the "renegade team" that literally battles the politically appointed leadership on its own political turf is much rarer. Whether the OSHA experience may be translated to EPA is an open question, but it is a possibility that should not be ignored.

These disadvantages of the team model from the policy management perspective may be viewed as advantages from the broader perspective of Congress and the public. The concept of the bureaucracy as an inertial force is certainly not new, and it may contribute to the overall stability of a regulatory program. Few regulatees and beneficiaries of regulation are wellserved by a bureaucracy that swings wildly between policy extremes as administrations change or as new disaster stories reach the media. Nevertheless, a strong team model tends to distance regulatory policymaking from the electorate and to expand the discretion of unelected experts.

\section{B. The Hierarchical Model}

Under the hierarchical model, a single office is responsible for all aspects of a rulemaking initiative except for the final determination of whether the rule is consistent with the particular statute involved. The program office initiates the rulemaking effort; it gathers data and information; it identifies the relevant options and narrows them; it prepares the relevant support documents and economic analyses; and it bears responsibility for the completed package as it moves up the agency hierarchy. The program office rarely calls upon outside scientific or technical expertise, nor does it abide skeptical regulatory analysts and their constant worries about the costs of agency proposals. Enforcement concerns are met insofar as the program office is aware of and decides to deal with them. Although the agency lawyers can veto an initiative at late stages of the rulemaking process on the ground that it exceeds the scope of the statute, any input they might have on the adequacy of the technical basis for the rules may freely be ignored. ${ }^{107}$

105. In defense of some of the "renegade teams" at OSHA, the upper-level management during those years did at times insist that the teams adhere to extra-statutory policies that ran diametrically counter to prior agency goals. While some of the external criticism that the agency received was well deserved. the point here is that the team model produced a surprisingly independent roadblock to the new administration's policy initiatives.

106. See Sidney A. Shapiro \& Thomas O. McGarity, Report from the Office of the Chairman Administrative Conference of the United States to the Assistant Secretary for Occupational Safety and Health, OSHA, on OSHA Rulemaking Procedures (Feb 19, 1987). See also McGarity, Reinventing Rationality at 218-19 (cited in note 6).

107. Landy, Roberts, and Thomas appear to advocate a version of the hierarchical model for all EPA decisionmaking. They recommend that the agency be restructured into a "divisional" form of organization under which each assistant administrator would be responsible for all aspects of rules in 
The hierarchical model is followed in most regulatory programs in the U.S. Department of Agriculture. For example, in the Agricultural Stabilization and Conservation Service, a commodity specialist in the program office drafts the "work plan" for a rule; prepares all of the support documents and an options memorandum for the "policy guidance session" (mid-level review meetings closely resembling Steering Committee review in EPA); prepares a closure memorandum for the policy guidance session; drafts the proposed rule, preamble, supporting documents, and the regulatory impact analysis; prepares a summary of outside comments after the notice and comment period for a subsequent policy guidance session; and drafts the final rule and supporting documentation and analyses. ${ }^{108}$

EPA probably adhered to an impure version of the hierarchical model in its early years, and it still resorts to that model on occasion. For example, in the early 1970s, the Office of Pesticide Programs was very insular, even though it was increasingly apparent that pesticides had very important crossmedia impacts. Regulations and pesticide cancellation actions made their way up the hierarchy within the Office of Pesticide Programs with little input from other offices until reaching Red Border Review. ${ }^{109}$ After several successful judicial actions by environmental groups forced EPA to initiate cancellation hearings for a group of important pesticides, the locus of decisionmaking power for these actions shifted for a brief time to OGC, which likewise adhered to the hierarchical model. OGC secured funds to hire outside experts to testify in pesticide cancellation actions and otherwise to advise the office of which additional regulatory actions should be undertaken. The program office learned of major actions (such as the suspension of heptachlor/chlordane) in the newspaper. ${ }^{110}$

EPA tends to resort to the hierarchical model when the agency is under great pressure from outside sources to accomplish something in a hurry. A good example is the agency's resort to the hierarchical model in 1979-80

\footnotetext{
a given "line of business." "Such units would include all the types of expert needed to develop and manage a complete program, incorporating them into an organizational context which forces them to confront a broader definition of their responsibilities." Landy, Roberts \& Thomas, Asking the Wrong Questions at 298-99 (cited in note 1). While this kind of reorganization would have several advantages, it would also have many of the serious disadvantages of the hierarchical model discussed above. One of the primary disadvantages would be the inevitable decline in the influence of the agency's regulatory analysts, who would apparently be relegated to the already existing subunits within each of the program offices. It is unclear whether the authors would split OGC up and send the lawyers to the relevant program offices. If so, the agency could lose a great deal in consistency of legal approach to similar legal problems. In both instances, the agency would no doubt lose much in the way of independence of analysis.

108. See McGarity, Reinventing Rationality at 194-97 (cited in note 6).

109. See Christopher J. Bosso, Pesticides and Politics 183-84 (U Pittsburgh Press, 1987). Perhaps because they are so numerous, pesticide colerance actions still receive very little input from the other offices. Although the team model is putatively in effect, for all but the most controversial policy calls (for example, whether the agency will use a de minimis approach toward implementing the Delaney Clause), the hierarchical model dominates.

110. This arrangement came to an abrupt end after powerful congresspersons from agricultural states almost succeeded in returning jurisdiction over pesticide cancellation actions to the Department of Agriculture.
} 
when the courts and Congress pressed the agency to promulgate regulations for hazardous waste generation and disposal. Ultimately, the Assistant Administrator for Solid Waste seized control of this initiative to the exclusion of the other offices. During this period of intense activity,

[t]he agency's internal procedures proved inadequate to the task of creating such a complex program. [Assistant Administrator] Jorling, and his successor, Beck, reduced the "red border review" process and the attendant working groups and steering committees to a hollow ritual. If the Office of Solid Waste did not know enough to think clearly about its own problems, the Office of Policy and Management [now OPPE] and OGC knew even less. In the absence of an explicit problem definition and an associated strategy, there was only a mass of intricate detail, a series of esoteric choices whose significance and consequences remained obscure. ${ }^{111}$

Largely for historical reasons having to do with the requirements of a consent decree, 112 the Office of Water Regulations and Standards has at times followed a hierarchical pattern in promulgating effluent limitations and guidelines for new and existing sources of water pollution. A working group composed of an engineer, an economist, a statistician, an environmental specialist from the Office of Water Regulations and Standards, an attorney from OGC, and a regulatory analyst from OPPE typically prepares the rulemaking documents and the regulatory analysis documents. As a practical matter, however, the attorneys and the regulatory analysts rarely participate until the proposed rule is nearly finished. The working group then presents options and a recommendation to the director of the Office of Water Regulations and Standards in a single meeting. Afterwards, the same group meets with the assistant administrator for water, the assistant administrator for policy, planning and evaluation, and the general counsel to work out any remaining disagreements. This procedure follows an attenuated version of the team model at lower levels but abandons it at higher levels, thereby avoiding Steering Committee review. However, this procedure can allow high-level input at relatively early stages in the development of rules.

The greatest advantage of the hierarchical model is that it conserves agency resources and avoids delays. A single office (and in some cases a single agency employee) produces the proposed and final regulations and all of the important documentation in accordance with its own time schedule. Like its military analog, the hierarchical model provides clear and direct lines of authority and accountability. If deadlines slip, upper-level decisionmakers know whom to blame.

The hierarchical model also lodges policymaking in the entities that are the most knowledgeable about the complex issues that arise on a day-to-day basis-the program offices. Staff employees in the program offices develop expertise in the narrow areas encompassed by the rules they draft, and they tend to derive satisfaction from both this expertise and the de facto

111. Landy, Roberts \& Thomas; Asking the Wrong Questions at 125 (cited in note 1).

112. Environmental Defense Fund, Inc. v EPA, 8 ERC 2120 (D DC 1976). See Kris Hall, The Control of Toxic Pollutants under the Federal Water Pollution Control Act Amendments of 1972, 63 Iowa L. Rev 609 (1978). 
policymaking power they possess, albeit at a micro-policy level. The model is especially useful for programs involving highly technical issues that lack significant policy components and for which discretion is sufficiently limited that exploring a wide range of options would not be especially useful. The hierarchical model is most appropriate when the agency's statute articulates clear policy goals and provides the agency with very little discretion. In short, the hierarchical model makes sense where either the relevant science or the agency's statutory directives are so clear that agency officials can exercise little policy discretion.

Perhaps the most obvious drawback of the hierarchical model is its extremely limited capacity to bring multiple perspectives to bear on complex regulatory problems. Other disciplines can be heard, but only after the program office has explored all of the options that it cares to and has arrived at a preferred alternative. A single person is not likely to have sufficient expertise to address the bulk of the relevant issues in all but the most simplistic of EPA's regulatory programs. Likewise, a single program office is usually incapable of formulating a competent multimedia approach to regulating pollutants. In the area of environmental regulation, where an interdisciplinary perspective is essential, the quality of the final rulemaking product may suffer under the hierarchical model. The end result may be a lower rate of success on judicial review.

Because it does not allow for input from various perspectives, the hierarchical model may also be less adept at inducing agency staff to identify innovative options for solving regulatory problems. For example, the program office is not likely to have much expertise in identifying marketoriented approaches to environmental problems, such as the bubble policy, pollution taxes, and marketable permits.

In addition, animosities can arise when one group of agency professionals believes that its advice is not being heeded, and, as a result, morale in other offices may suffer. Since the hierarchical model does not assign to any office the function of taking a critical look at the program office's work product, bad ideas may go out over the administrator's signature, and the agency may experience a humiliating comeuppance when outside commentators or reviewing courts point out obvious flaws in the agency's proposal during the notice-and-comment stage.

Finally, the hierarchical model may not work well in programs that must deal with large data gaps and highly uncertain predictive models. In such wide-open regulatory contexts, where costs and benefits are not easily reduced to a common coin, the decisionmaking process can usually profit from a healthy intra-agency debate before the regulation hits the streets and becomes the subject of external public criticism.

\section{The Outside Advisor Model}

The outside advisor model makes better use of agency experts outside the program office without thoroughly incorporating them into the 
decisionmaking process. Under this model, the program office retains primary responsibility for drafting the proposed and final rules and the attendant supporting documentation. However, the program office is free to call upon other offices in the agency for advice as needed, and they are obliged to provide input when requested. The outside advisor model differs from the team model in that the other offices are not officially part of the decisionmaking process. They speak when spoken to, do not regularly participate in important decisionmaking meetings, and do not have formal sign-off authority.

The outside advisor model is in use in many federal agencies. When the assistant secretary for OSHA abandoned the team model to avoid renegade teams, the agency substituted the outside advisor model. That model also accurately describes the relationship between the program office engineers and the agency regulatory analysts in the Federal Aviation Administration. ${ }^{113}$ Most regulations in that agency are drafted by a team of program office staffers, consisting mostly of engineers, with minimal day-to-day participation by the agency's attorneys. When the engineers in the program office need additional expertise, they ask the agency's economists to participate in team meetings and to draft necessary economic documents. ${ }^{114}$ However, the final say, even over the content of the economic documents, belongs to the engineers.

The great advantage of the outside advisor model is that it allows the agency to bring multiple perspectives to bear on regulatory problems while maintaining clear lines of authority and responsibility for the total rulemaking effort. Like the hierarchical model, the outside advisor model can conserve resources and avoid delays, because the decisionmaking process need not get bogged down in lengthy debates in which other offices demand more data and analysis. The model conserves valuable professional resources for those important junctures in the rulemaking process where they are really needed. For example, officials from the enforcement office can be brought into the decisionmaking process for the limited purpose of addressing the enforceability of particular regulatory options without subjecting the decisionmakers to their opinions on other issues, such as the legitimacy of the economic cost projections. In addition, the professionals in the program office usually prefer the outside advisory model because it maintains their decisionmaking prerogatives. Staffers from outside the program office are not allowed to dominate the rulemaking process through the force of their personalities or through extortionate threats to delay. Project leaders in the program office can call upon agency expertise whenever they need it, without

113. See McGarity, Reimventing Rationality at 204-07 (cited in note 6).

114. There is some evidence that EPA program offices with their own regulatory analysts use those analysts in the manner suggested by the outside advisor model. See id at 253-54. But the regulatory analysts in OPPE are definitely equal participants in the workgroup meetings in which important decisions are made. 
necessarily accepting the attitudes and biases that come with the outside professional perspectives.

The outside advisor model also has its disadvantages. To the extent that the outside professionals are not true participants, there is a risk that their input will be misinterpreted by program office staffers or that the program office will hear only that which it wants to hear, without listening to important qualifiers. At the extreme, the outside advisor model may allow the program office to attach an interdisciplinary patina to decisions actually dominated by a single perspective. The outside professionals may complain, with some justification, that their perspectives are solicited not to reach better decisions, but solely to justify decisions reached on other grounds. As with the hierarchical model, the outside advisor model does not allow the outside offices to play a role in identifying options. Similarly, the absence of an institutional skeptic outside the program office may result in poorly reasoned approaches finding their way into the Federal Register. Finally, the outside advisor model is no more likely to achieve an integrated cross-media approach to regulation than the hierarchical model.

\section{The Adversarial Model}

The adversarial model forces staffers with different perspectives to confront one another in an adversarial setting. Each office is responsible for assembling its own information and analyses and for critiquing the information and analyses of the other offices. Disagreements over facts, assumptions, inferences, or policies are aired in an adversarial fashion, either in memoranda or in oral presentations, before the ultimate agency decisionmaker. Although it is conceivable that the adversarial model could incorporate three or more offices within a single agency, it is typically limited to two offices with widely differing perspectives, usually the program office and the policy office.

The National Highway Traffic Safety Administration ("NHTSA") has employed the adversarial model for a number of years in writing automobile safety standards. ${ }^{115}$ NHTSA leadership has made a conscious effort to play the program office and the policy office against each other until fairly late stages of the internal decisionmaking process. After the program office obtains upper-level approval to undertake a rulemaking initiative, it begins to assemble data and analyses on the effectiveness and costs of several alternative approaches. At roughly the same time, the policy office begins to prepare a regulatory analysis document and conduct an independent examination of the relevant data on the costs and effectiveness of different alternatives. There is relatively little contact between the two offices until each has completed its initial work, at which point each office examines and critiques the work of the other. Since the program office approaches the effort from a strong engineering perspective and the policy office approaches

115. See id at 229-34 
it from an equally strong economics perspective, it is not surprising that the two offices usually disagree on the appropriate approach to take and upon other significant aspects of the rulemaking. After the two offices attempt to reconcile their differences, any remaining disputes are resolved by the administrator after each side has a full opportunity to present its position, either orally or in writing. The program office's product has often changed dramatically as a result of the internal dialectic with the policy office, and there can be little doubt that the model has had a profound effect on the substantive outcome of NHTSA rules.

Although EPA's administrator has no doubt witnessed debates that are very similar to the adversarial meetings before NHTSA's administrator, internal conflicts are not consciously structured into EPA's decisionmaking process. EPA's policy office constantly reviews and critiques the work of the program offices, and great clashes of perspectives often result. But in EPA there are strong pressures to avoid such clashes and instead achieve consensus. Upper-level decisionmakers make no effort to harness the natural adversarial tensions and direct them toward creative ends.

The great advantage of the adversarial model is its ability to maximize the decisionmaker's discretion by making him or her aware in stark (sometimes overstated) terms of the pros and cons of several important options. Unlike the team model, in which a great deal of decisionmaking discretion is exercised at fairly low levels, the adversarial model discourages low-level compromises on important regulatory issues without upper-level input. It is highly unlikely that the professionals in one office will be co-opted by another office under the adversarial model, and innovative options will probably not be rejected out of any perceived need to reach an overall staff consensus. Upper-level decisionmakers in NHTSA believe that the "creative tension" spawned by the adversarial approach is the best way to ensure that the staffprepared decision memoranda are not loaded in favor of a particular option. They believe that the adversarial process "not only produces the best possible data and analysis, but also provides the Administrator with the most independent and objective advice for arriving at the best possible rulemaking decisions." 116

The adversarial model also reduces the incidence of purely technical errors, because virtually every prediction and calculation receives the intense scrutiny of a skeptical adversary within the agency. Moreover, the adversarial model inhibits the natural tendency of bureaucrats to ignore or belittle information that undercuts their position. Each office can be confident that any failure to portray data accurately or to avoid the negative implications of existing studies will come to the decisionmaker's attention before the rule leaves the agency. By fostering the broadest possible exchange of information and analysis, the adversarial approach can go a long way toward

116. Regulatory Reform Act 248, Hearings on HR 2327 before the Subcommittee on Administrative Law and Governmental Relations of the House Committee on the Judiciary, 98th Cong, Ist Sess (1983) (testimony of Mr. Frank Berndt, chief counsel, NHTSA). 
exposing hidden agendas in both offices. In the long run this is a virtue, because it helps the agency avoid embarrassment later in the rulemaking process. 117

If the regulatory analysis office becomes a major player under the adversarial model, agency decisions will reflect to a greater degree than under other models the economic perspective that characterizes that office. The regulatory analyst's market-oriented policy preferences will receive a full airing in the agency's internal debates. If the agency's regulatory analysts are effective advocates, they may become influential determiners of agency policy.

The primary disadvantage of the adversarial model is that it requires duplication of agency effort that is extremely resource intensive. Each of the two or more offices that participate in the process performs many of the same data gathering, analysis, and review functions. In addition, the tendency of the adversarial model to discourage the early sharing of information can result in unnecessary waste of precious analytical and technical resources later in the process. For example, if the policy analysis office identifies a number of options that the program office has failed to study, there is a real possibility that the program office may have to redraft its documents and perhaps even undertake further research, thus delaying the rulemaking efforts. The program office also may have to scramble to find or produce data on a fresh option, or it may simply attempt to amend existing documents to include the new option, thereby increasing the likelihood of technical mistakes.

While one of the adversarial model's great advantages is its capacity to expand the choices available to upper-level decisionmakers, it likewise

117. Some commentators have suggested that an adversarial proceeding before an expert "science court" may be the best vehicle for resolving intricate science/policy disputes about which the relevant experts disagree. The adversarial model could in a similar fashion be adapted to the Science Advisory Apparatus by encouraging sharp debate between competing offices or suboffices before the appropriate science advisory committee. EPA Science Advisory Board meetings tend to be exceedingly civilized affairs with little internal dissention among the agency staff. The adversarial qualities the process currently possesses stem from the participation of outsiders from industry and environmental groups. Allowing EPA's internal advocates to debate technical points before a group of experts could broaden the range of information and analysis available to the scientists in the scientific advisory apparatus.

The most serious impediment to adapting the adversarial model to intra-agency disputes before science advisory committees stems from the fact that under the Federal Advisory Committee Act, 5 USC App $\S \S 1$ et seq (1985), Pub L No 92-463, 86 Stat 770 (Oct 6, 1972), advisory committee meetings must be open to the public. The agency may not always be willing to air internal disputes in a public forum.

Perhaps a greater disadvantage of the "internal science court" idea stems from the fact that the issues about which adversarial disputes are likely to erupt are not questions of pure science, but must be decided by reference to appropriate regulatory policies. See McGarity, 67 Georgetown L J 729, 731-49 (cited in note 104). Yet these are precisely the kinds of issues that should not be resolved by unaccountable advisory committees, because they are no more expert in choosing the appropriate regulatory policy for resolving science/policy disputes than the agency decisionmakers. Indeed, upper-level decisionmakers who routinely defer to the science advisory apparatus to resolve science/policy questions are in a very real sense shirking their statutory duty to decide science/policy questions in accordance with statutory policies. Adapting the adversarial model to agency presentations to science advisory committees may help sharpen the agency's understanding of critical scientific questions, but it should be attempted only for relatively "pure" questions of science and not questions with large policy components. 
demands more of their time and attention. The model encourages dissent at low levels and forces upper-level decisionmakers to resolve the disputes. Because there is no predetermined place in the decisionmaking process for selecting among regulatory options, disputes requiring upper-level attention can erupt at almost any time. Upper-level decisionmakers must therefore maintain a continuing familiarity with the complex issues in the ongoing internal proceedings.

The tension that the adversarial model generates may not necessarily be "creative."118 Organizational subunits in large bureaucracies are already prone toward pettiness, "turf consciousness," and personality conflicts. The conscious adoption of an adversarial decisionmaking approach may divert even more energy into petty bickering, "one-upmanship," and other unproductive activities. The disputants may begin to lose sight of the agency's broader goals in their desire to win intra-agency battles and enhance the institutional status of their offices. At the same time, the adversarial model risks damage to agency morale if one office loses intra-agency disputes more frequently than the others.

Substantive decisions under the adversarial model may depend too greatly upon the advocacy skill of the personnel in the various offices. If one of the contending offices is blessed with an able advocate for a leader, it may win more regulatory battles for this reason alone. This is especially true if OGC is one of the advocates. But the fact that the lawyer can make a better case for his or her position than the scientist does not mean that the agency's decisions will win more support in external forums. On the other hand, upper-level decisionmakers, like good judges, should acquire over time the ability to discount this factor sufficiently to reach sound regulatory decisions, even if it means ruling against the better advocate.

\section{E. The Hybrid Model Formerly Employed at EPA}

During the second Ruckelshaus Administration, Deputy Administrator Alvin Alm implemented an ambitious hybrid decisionmaking model for EPA rulemaking that incorporated many of the virtues of both the adversarial and team models, while avoiding some of their pitfalls. Labelled the "options review process," the model's primary aim was to maximize upper-level input into lower-level decisionmaking in a systematic fashion. ${ }^{119}$

All major and significant rules were required to go through this options review process. ${ }^{120}$ Early in the development of a major or significant regulation, the deputy administrator designated it for either Level I or Level II options review. ${ }^{121}$ The Level I determination indicated that a rule would receive more intense upper-level scrutiny. The assistant administrators for

118. See Marcus, Promise and Performance at 106 (cited in note 1).

119. See McGarity, Reinventing Rationality at 243-51 (cited in note 6).

120. Procedures Memo at 2 (cited in note 41).

121. Memorandum on Options Selection/Rejection Process from Alvin L. Alm, EPA Deputy Administrator to EPA Assistant Administrators and General Counsel, Nov 4, 1983. 
the regulatory programs nominated candidates for Level I options review. Although the assistant administrators and their immediate staffs drew upon lower-level staff for suggestions and information, the decision whether to nominate a rule for Level I options review was made at a very high level within the program office. In nominating regulations for the options review process, the assistant administrators took into account the cost of the rule, the likelihood that it would generate public controversy, and the importance of the rule to the regulatory program. They also looked to the precedential value of the rule for future agency rulemakings and to the probability that the rule would require the agency to resolve major cross-program policy issues. The importance of the options review process was underscored by the fact that only about twenty to thirty rules per year could be designated for Level I review.

The options review process for Level I rules was implemented through quarterly planning meetings and more frequent options selection/rejection meetings chaired by the deputy administrator. The quarterly planning meetings were intended to (1) provide a status overview of all Level I rules; (2) provide advance notice of rules that would be ripe for an options selection/rejection review during the quarter; and (3) decide which assistant administrators and regional administrators should participate in particular options selection/rejection meetings. ${ }^{122}$ Options selection/rejection meetings were held for individual regulations at crucial decision points in the rulemaking process. Since Deputy Administrator Alm had a strong preference for resolving potential intra-agency disputes at a very early stage, these meetings were usually scheduled at early points in a workgroup's decisionmaking. The precise timing of the first meeting was somewhat flexible. It was supposed to occur early enough in the rulemaking process that options were realistically available, but late enough to provide the workgroup an opportunity to analyze the problem and the existing data sufficiently to crystallize the thinking of its members. More than one meeting could be scheduled prior to the promulgation of the proposed rule if other issues needing high-level input arose during the workgroup's deliberations.

For all Level I rules, the lead office prepared an options memorandum for the review meeting and circulated it to the members of the committee. ${ }^{123}$ The memorandum was supposed to identify several options (perhaps six or seven) that the upper-level policymakers could narrow to a smaller range of options (perhaps three or four) for consideration in detail prior to the publication of the Notice of Proposed Rulemaking. The program office staff attempted to identify and explain a broad range of options without going into such an extensive explanation of any particular option that the upper-level decisionmakers would get bogged down in the details. On the infrequent occasions in which the available range of options was quite limited, the

122. Id.

123. Criteria and Guidelines Memo at 5-6 (cited in note 41). 
options review meeting was essentially limited to choosing between the options of going forward with the proposed rule or doing nothing.

At the options selection/rejection meeting, the high level participants attempted "to agree on which options to retain for further development and which to reject."124 The meeting was also an appropriate place for an office to suggest an option that the program office rejected or otherwise failed to include in the options memorandum. The participants at the meeting, who included the relevant assistant administrators and the deputy administrator, would then decide whether the lead office should analyze and consider the neglected option. ${ }^{125}$ The more serious discussion at the first meeting concerned the selection of three or four preferred options from among the options listed in the options memorandum. This meeting was thus an early forum in which any office could candidly raise questions about the substantive advantages and disadvantages of the regulatory options that the program office selected. Since one of the options was nearly always to do nothing, this meeting also presented an opportunity for institutional skeptics (usually in the Office of Policy Analysis) to question the need for any regulation at all.

In approximately 50 percent of the meetings, the Office of Policy Analysis took a position that varied significantly from that of the program office, and the staff of the Office of Policy Analysis occasionally drafted a separate memorandum setting out the nature of the disagreement and the arguments favoring its resolution of those issues. Debates about whether to pursue an option further were most likely to arise when the program office took the position that it lacked the authority to choose that option. In such cases the program office was reluctant to expend analytical resources to study an impossible option, and OGC often weighed in on the program office's side of the dispute. ${ }^{126}$ If the options review committee could not reach consensus, the dissenters could have their recommendations included in the closure memorandum, which served as a vehicle for documenting the meeting's results and for explaining remaining disagreements to the deputy administrator and ultimately the administrator. ${ }^{127}$

Although the options selection/rejection meeting was very effective in selecting a few options from among the options suggested by the workgroup for more intense analysis, the participants at those meetings rarely identified

124. Procedures Memo at 7 (cited in note 41).

125. Before the assistant administrators committed themselves to engage in a debate before the deputy administrator over the failure of the lead office to include an option in the Options Memorandum, they would usually instruct their staffs to attempt to work out their differences, and the assistant administrators themselves may have met with each other to arrive at a solution. At this stage of the process, compromise was not normally difficult, because a decision to include an option in the Options Memorandum merely allows the deputy administrator to consider the option; the lead office may still argue that the option should be rejected.

126. See, for example, Alm to Decide Risk Assessment Funding Squabble on Waste Tank Regs, 5 Inside EPA 3 (June 29, 1984) (debate between Office of Solid Waste and Emergency Response and OPPE over whether a risk assessment for technology-based regulations should be prepared and, if so, who should pay for it).

127. Procedures Memo at 7 (cited in note 41). 
new options that the workgroup participants had failed to spot. The options selection/rejection meetings could also reveal gaps in the available information that were so substantial that the deputy administrator remanded the project for further data gathering and analysis. ${ }^{128}$

After the workgroup finished its deliberation for Level I rules, it could prepare another options memorandum listing the advantages and disadvantages of the options that it studied following the first Level I meeting. If the deputy administrator decided that the issues were sufficiently important, he could schedule a second options selection/rejection meeting prior to sending the package to the administrator. Later, after the workgroup had finished digesting the public comments on the proposed rule, still another options selection/rejection meeting could be scheduled to allow the deputy administrator to narrow the options still available to the workgroup for the final rule.

The options review process had five goals. First, upper-level decisionmakers viewed the Level I options selection/rejection meeting as "an institutional mechanism for forcing consideration of a much broader spectrum of approaches to the regulatory problem."'129 Having forced lowerlevel staff to identify a broad range of options, a second purpose of the process was to allow high-level policymakers to narrow the range of options that the workgroup considered and, as the rulemaking process progressed toward completion, to select the option that would go forward to the administrator and OMB as the agency's preferred option. ${ }^{130}$ Third, by forcing mid-level management to consider the implications of many options for all institutionally important decisions, the process was intended to make mid-level (career) management more accountable to high-level (politically appointed) management. ${ }^{131}$ Fourth, by assigning a prominent role to the agency's regulatory analysts, the process was intended to eliminate the perception on the part of the technical staff in the program offices that the regulatory analysts were officious intermeddlers in the decisionmaking process. ${ }^{132}$

Finally, the options review process was intended to give upper-level management a greater role in the subtle policymaking that inevitably takes place at low levels in the bureaucracy when options are examined and rejected as the workgroup members attempt to reach consensus. The new management team that came to the agency with Administrator Ruckelshaus

128. The workgroup itself served as the Options Review Committee for Level II rules. When it submitted its final decision package for Steering Committee and Red Border Review, the lead office included a summary of the options that the workgroup considered and rejected, stating when and why each was rejected. Procedures Memo at 7 (cited in note 41 ). The Steering Committee meeting then performed much the same function for Level II and other rules that the Options Review meeting performs for Level I rules.

129. Personal interview with Mr. Rob Wolcott, Special Assistant to the Deputy Administrator, EPA, June 27, 1984 ("Wolcott Interview").

130. Criteria and Guidelines Memo at 5 (cited in note 41).

131. Wolcott Interview (cited in note 129).

132. Id 
believed that high-level policymakers were able to play only a small role in the decisionmaking process under the team model because the consensusbuilding process in the workgroups eliminated most viable options before rules went forward for upper-level review. In most cases, as noted above, the workgroup process effectively lined up all of the relevant institutional entities behind a single recommendation to the administrator. The administrator in reality had only two options: he could accept the recommendation, or he could send everyone back to square one. The practical effect of this situation was that much agency policy was made at the level of the branch chiefs. The new administration created the options review process as a vehicle for retaining the benefits of the team approach (such as information sharing and a multidisciplinary perspective) while enhancing the role of the politically appointed upper-level management in the decisionmaking process.

Although there is no evidence that the agency failed to meet these goals in any significant way, the options review process was abandoned not long after Administrator Thomas succeeded Administrator Ruckelshaus. One reason for the tacit decision to abandon the process was the fact that Deputy Administrator Alm, who had a great personal stake in the success of the process that he designed, left the agency with Ruckelshaus. His successor was not a take-charge decisionmaker, and (according to some agency officials) he was apparently uncomfortable with the pressure that the process placed on him to make on-the-spot decisions. In any event, it appears that Administrator Thomas was not willing to cede much decisionmaking power to his deputy. After a short time during which Thomas himself chaired the options selection/rejection meetings, the options review process was quietly abandoned.

Although the hybrid options review model has been abandoned, it still has much to commend it. First, it shares the team model's ability to bring different perspectives to bear upon information gathering and data evaluation. That aspect of the rulemaking process is still very much in the bailiwick of the workgroup under the hybrid model. Second, by forcing lower level staff to analyze a broad range of realistic options prior to the options selection/rejection meetings, it reduces the workgroup's tendency to exclude options that might be controversial and therefore fracture the group's consensus. Third, by giving all of the designated participants a "day in court" before one of the highest level agency decisionmakers early in the process, while many options are still alive, it interjects a creative adversarial note into the agency deliberations thereby reducing the potential for groupthink. Fourth, the process reduces the risk of alienating the office on the losing side of important policy debates, because the deputy administrator hears both sides of all arguments and often decides issues in the presence of the staff, and not later after an opportunity for insider lobbying. Fifth, by forcing all branches of the agency to identify options early in the process, it helps ensure against the "late hit phenomenon," where one office brings up an option very late in the process and urges the program office to slow the process while that 
option is being considered. Finally, the model retains the adversarial model's capacity to maximize the decisionmaking discretion of upper-level decisionmakers and thereby reduces the likelihood of "staff capture." 133

The hybrid model, however, has many of the disadvantages of the team and adversarial models, although in somewhat moderated forms. First, the model is very resource intensive, especially at upper-levels. The process demands a great deal of the attention of very high-level decisionmakers. Yet the key to its success is their willingness (and ability) to devote the time and intellectual effort necessary to prepare for the sometimes grueling review meetings. Although Administrator Ruckelshaus, who inaugurated the process, devoted very little attention to it, his deputy administrator was committed to the process and devoted a great deal of energy to the process. In the hands of less dedicated upper-level decisionmakers, the process rapidly reverted to the team model.

A second disadvantage is that the options review process may force closure too rapidly on very important issues without the reflection necessary for informed decisionmaking. A single three-hour meeting with the key staff and the administrator or deputy administrator may not be sufficient to air all of the important issues. Critical options may be eliminated because the proponents of one side of the debate are better advocates, rather than because their position is best for the agency. The administrator may need time to mull over the arguments pro and con in private or with a few trusted advisers, rather than decide issues with enormous consequences on-the-spot.

Despite the problems, the hybrid model appears to be an extremely effective vehicle for communicating policy. The essence of the model is that it gives upper-level decisionmakers greater input into the decisionmaking process at an early stage. The content of that input, which can obviously be very influential in the workgroup meetings that follow, depends upon the policy preferences and thoughts of the deputy administrator or the administrator. In a democracy, in which the bureaucracy must ultimately be held accountable to the public, this is as it should be.

\section{VI}

\section{Future Directions for EPA}

This article has examined how structured approaches to integrating various professional perspectives into EPA's decisionmaking process can both facilitate the promulgation and change the substantive content of EPA rules. Obviously, structure is not the only determinant of EPA decisionmaking. Institutions external to EPA, such as congressional committees, OMB, and the reviewing courts, all exert exceedingly powerful pressure on the agency and

133. Staft capture, a malady much feared by OMB officials, occurs when a politically appointed official becomes so immersed in day-to-day briefings by the agency's professional staff that he or she loses his or her objectivity (or perhaps ideology) and begins to view the world from the staff's perspective. 
are quite capable of bogging down the rulemaking process in interminable delays and of steering the agency in particular directions.

Agency structure may not even be the most important internal determinant of EPA rulemaking. The unique administrative talents, leadership abilities, and foibles of the administrator and the perception of the administrator's personal strengths and weaknesses no doubt have a profound impact during his or her (usually brief) tenure.

Likewise, the personalities of the public servants who occupy leadership positions in the agency undeniably play a role in the allocation of power within the agency. And the allocation of institutional power is in turn reflected in the agency's substantive output. For example, during the second Ruckelshaus Administration, the powerful deputy administrator's strong analytical bent ensured that EPA regulatory analysts were "top dogs" in internal agency debates, and the agency's substantive output was often more sensitive to cost considerations.

Yet the importance of personalities should not be overemphasized. People come and go. When Deputy Administrator Alm was succeeded by the former general counsel, the agency's analysts were no longer invited to private tête-à-tête with the deputy administrator, and their office was reduced to the status of equal among equals. Not surprisingly, agency decisions, particularly in the area of hazardous wastes, became somewhat less cost sensitive.

EPA engaged in an unorthodox experiment in modifying the role of individual players in 1985 when the administrator reassigned office directors to different offices. ${ }^{134}$ In addition to injecting new blood into some anemic programs, this shift tended to reduce the effect of personality on the substance of agency rules. The NHTSA undertook a similar experiment in 1985 when it allowed the head of the regulatory analysis office to become the head of the program office. EPA should continue to experiment with such personnel trades to allow the professional perspectives upon which the agency's expertise is built to interact freely, without being constrained by powerful personalities.

Although agency structure may not be everything, it counts for something, and usually it counts for a lot. Strong personalities of mid-level bureaucrats, firm bonds of trust between upper-level decisionmakers, and the particular predilection of the administrator and deputy administrator all can decisively determine the priority status and substantive outcome of a few particularly important rules. But over the course of day-to-day decisionmaking, the structure of the decisionmaking process may be the most important determinant. In any event, even when an administrator or deputy administrator has a strong desire to drive the substantive output of agency rules in a particular direction or when a strong mid-level official becomes a

134. Seven Senior EPA Officials Reassigned by Thomas in Ongoing Management Changes, 16 Envir Rep 542 (August 2, 1985). 
powerful bureaucratic actor, the vehicle for implementing substantive change is structural. For example, the clearest measure of the decline of the status of EPA's regulatory analysts after Deputy Administrator Alm left the agency was the structural fact that OPPE no longer had a de facto veto power over important agency rules. The agency's formal decisionmaking documents may not have announced this power shift, but it was no doubt reflected in the substance of the rules.

EPA has in the past relied heavily upon the team model. Undoubtedly, this has contributed substantially to the coherence and consistency EPA decisionmaking has exhibited over time. The team model has enabled EPA decisions to reflect multiple perspectives, but it has also ensured that few truly innovative regulatory approaches have survived the consensus building process that characterizes the model. The bubble policy, which emerged from the agency after years of internal debates, was an innovative regulatory tool, but it is the notable exception that proves the general rule that the agency adopts a cautious approach that minimizes internal conflict and maximizes the probability of successful judicial and political review. In short, EPA decisionmaking under the team model is competent, but boring. This may be altogether appropriate; bureaucracies are not usually exciting places, nor are they meant to be. Yet even a bureaucracy must maintain some vitality if it is to attract and keep intelligent young staffers. Consensus-building helps maintain stability, but dissent inspires creativity and enhances the ability of upper-level political appointees to lead.

EPA decisionmaking under the team model is also very slow. Although much of the time consumed while a rulemaking initiative is pending in the agency is attributable to the complexity of the issues and the consequent demand for data and analysis, the team model, with its lack of clear lines of accountability, no doubt exacerbates the problem. A hierarchical approach (as its military analog suggests) can get the job done in a hurry, but the product may be unidimensional. In an agency that constantly addresses multidimensional issues, such products may not survive judicial and political review. The adversarial model may lend creativity to the process, but it can be even more time consuming than the team model.

The agency need not hew to a single model for every decision. The team model, which is the predominant model for regulatory decisionmaking, is certainly a good starting point. Rulemaking initiatives presumptively should be governed by that model, but upper-level decisionmakers should consider supplementing or replacing it when it appears to be failing. The hybrid options review process, for example, is a superb compromise between the team and adversarial model, and it demands a high level of upper-level attention. For important rulemaking initiatives, upper-level decisionmakers should be out in front making important decisions, and the options review model helps ensure that critical decisions are made by the people who are paid to make them. But this hybrid model is much too demanding of upperlevel attention to routine rules. The agency should consider re-implementing 
the options review model for the most important ten to twenty rules it promulgates each year.

For other, more routine rules, the agency should consider greater use of the outside advisor model. In practice, the team model conforms to the outside advisor model for uninteresting rules, because workgroup meetings are attended by only the very few invitees with something to contribute. The problem with this de facto use of the outside advisor model is that it still leaves all members of the team with sign-off power. In addition to slowing the process, this fact also probably gives too much power to the absent regulatory analysts and OGC who can use the threat of delay to extract substantive concessions from the program offices. Although OPPE no longer displays the overt bias against regulation it once did, and although EPA decisions should reflect the analytical perspective of that office, it is not clear that OPPE must be an equal participant in regulatory decisionmaking for less important rules. Its input should be solicited, and on occasion demanded, ${ }^{135}$ but its approval should not be required.

The same may be true for the input of OGC. While its advice on matters of statutory interpretation is critical and cannot be ignored, its opinions on the substantive merits of regulatory decisions that come by way of its role as predictor of judicial reaction is essentially outside advice that the program office should be free to take or ignore. Both OPPE and OGC should be able to raise objections of any kind at the Steering Committee level to the extent that they have raised the objections to the program office during the rule's generation, but for most of the agency's unimportant rules, it is not apparent why either office should have a veto power on issues not involving statutory interpretation. Even if the agency elects not to return to the hybrid options review model, the distinction between Level I rules and Level II rules may be useful for targeting rules for full-fledged workgroups and rules for which a hierarchical or outside advisor approach will be adopted.

The Office of Enforcement and Compliance Monitoring, on the other hand, is rarely available even as an outside advisor to agency workgroups. Because the enforcement perspective is critical for rules that must be implemented in the field, the agency's enforcers should be encouraged to play a more prominent role in the rulemaking process for important rules. ${ }^{136}$ The agency's management should consider vehicles for inviting or demanding the participation of representatives from this office on workgroups or for requiring systematic responses to early drafts of proposed rules.

135. Many programs have internal regulatory analysts, some of which perform in an outside advisor capacity. For these offices, it may not be necessary to insist that OPPE play an additional outside advisor role.

136. A working group for EPA's Enforcement in the 1990s project recently recommended that the enforcement office play a greater role in the rulemaking process "to enhance the link between implementation and enforcement of a rule." Enforcement 1990s Group Recommends Changes for Management of EPA Activities in Next Decade, 21 Envir Rep 161 (May 11, 1990). 


\section{VII}

\section{Conclusion}

With the very notable exception of the turbulent early 1980s, EPA has acquired a well-deserved reputation as one of the most intelligently run agencies in the federal government. While its output has never been high, it has (with the above noted exception) been of increasingly high quality. In short, EPA has adapted well to the modern reality of complex scientific and technical rulemaking. In many areas, such as its innovative action tracking system, it has served as a model for other agencies. Yet there is always room for improvement. Perhaps more accurately, there is always room for adaptability as conditions change and as upper-level appointees come and leave. As it enters its third decade, EPA has come a long way, but it still has a long way to go.

Some observers have suggested that agencies undergo an evolution from vigorous youth to stable old age, ${ }^{137}$ and in the process the original goals become less important than the survival of the institution. The extraordinary transformation of EPA at the end of the Gorsuch fiasco and its recent reinvigoration under an administrator and president who at least talk like the environment matters suggest that this theory may be inaccurate. The environment is a better place than it was twenty years ago. If EPA can continue to evolve and to reaffirm its goals, it may be able to delay old age indefinitely. To a substantial degree this will depend upon the agency's ability to adapt its internal decisionmaking structures to changing internal and external realities. If EPA can successfully postpone old age, the environment will be a much better place twenty years from now than it is today.

137. See E. Donald Elliott, Bruce A. Ackerman \& John C. Millian, Toward a Theory of Statutory Evolution: The Federalization of Environmental Law, I J L. Econ \& Org 313 (1985); E. Donald Elliott, The Evolutionary Tradition in Jurisprudence, 85 Colum L Rev 38 (1985); William Rodgers, Jr., The Natural Law of Administrative Law, 48 Mo L Rev 101 (1983). 
